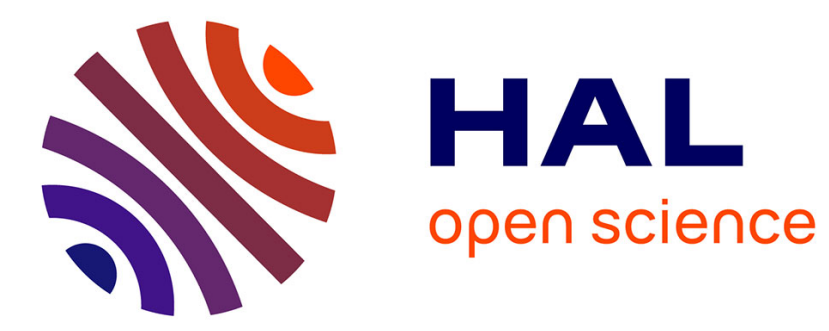

\title{
International portfolios, capital accumulation and foreign assets dynamics
}

Nicolas Coeurdacier, Robert Kollmann, Philippe Martin

\section{To cite this version:}

Nicolas Coeurdacier, Robert Kollmann, Philippe Martin. International portfolios, capital accumulation and foreign assets dynamics. Journal of International Economics, 2010, 80 (1), pp.100-112. 10.1016/j.jinteco.2009.05.006 . hal-01052901

\section{HAL Id: hal-01052901 \\ https://hal-sciencespo.archives-ouvertes.fr/hal-01052901}

Submitted on 29 Jul 2014

HAL is a multi-disciplinary open access archive for the deposit and dissemination of scientific research documents, whether they are published or not. The documents may come from teaching and research institutions in France or abroad, or from public or private research centers.
L'archive ouverte pluridisciplinaire HAL, est destinée au dépôt et à la diffusion de documents scientifiques de niveau recherche, publiés ou non, émanant des établissements d'enseignement et de recherche français ou étrangers, des laboratoires publics ou privés. 


\title{
International Portfolios, Capital Accumulation and Foreign Assets Dynamics ( $\sharp)$
}

\author{
Nicolas Coeurdacier (a,e) \\ Robert Kollmann (b,c,e, $\left.{ }^{*}\right)$ \\ Philippe Martin (d,e)
}

(a) Department of Economics; London Business School; Regent's Park; London NW1 4SA; United Kingdom

(b) ECARES; Université Libre de Bruxelles; CP 114; 50 Av. Franklin Roosevelt; B-1050 Brussels; Belgium

(c) Faculté de Sciences Economiques; Université Paris XII; 61 Av. du Gén. de Gaulle; 94000, Créteil; France

(d) Sciences Po; 27 rue Saint-Guillaume, 75007 Paris, France

(e) CEPR, 53-5 Gt. Sutton Street, London EC1V ODG, United Kingdom

May 16, 2009

\begin{abstract}
Despite the liberalization of capital flows among OECD countries, equity home bias remains sizable. We depart from the two familiar explanations of equity home bias: transaction costs that impede international diversification, and terms of trade responses to supply shocks that provide risk sharing, so that there is little incentive to hold diversified portfolios. We show that the interaction of the following ingredients generates a realistic equity home bias: capital accumulation and international trade in stocks and bonds. In our model, domestic stocks are used to hedge fluctuations in local wage income. Terms of trade risk is hedged using bonds denominated in local goods and in foreign goods. In contrast to related models, the low level of international diversification does not depend on strongly counter-cyclical terms of trade. The model also reproduces the cyclical dynamics of foreign asset positions and of international capital flows.

JEL classification: F2, F3, G1.

Keywords: capital accumulation;international equity and bond portfolios; capital flows; current account;valuation effects; terms of trade.

(\#) A Technical Appendix is posted on the corresponding author's web page. We thank Mick Devereux and two anonymous referees for helpful comments and advice. We also thank Kosuke Aoki, Matthias Doepke, Stéphane Guibaud, Viktoria Hnatkovska, Mathias Hoffmann and Giovanni Lombardo for detailed and constructive discussions. For comments, we are also grateful to Luca Dedola, Pierre-Olivier Gourinchas, Harald Hau, Jonathan Heathcote, Akito Matsumoto, Werner Roeger, Alan Sutherland and Pedro Teles, and to workshop participants at IMF-JIE conference "International Macro-Finance", AEA 2009, RES 2008, SED 2008, Bundesbank Spring conference, ESSIM (CEPR), EU Commission (DG ECFIN), Bank of Portugal, Bank of Italy, San Francisco Fed, Dallas Fed, EUI (Florence), Birkbeck, City University (London) and at the Universities of Zurich, Leicester and Gent. R. Kollmann thanks ECARES, the National Bank of Belgium and the EU Commission (DG ECFIN) for financial support. Philippe Martin thanks the Institut Universitaire de France for financial help

* Corresponding author. Send correspondence to: ECARES, Université Libre de Bruxelles; CP 114; 50 Av. Franklin Roosevelt; B-1050 Brussels; Belgium; Tel: 322650 3075; Fax: 322650 4475; www.robertkollmann.com

E-mail addresses: ncoeurdacier@london.edu,robert_kollmann@yahoo.com, philippe.martin@sciences-po.fr
\end{abstract}




\section{Introduction}

Cross-country capital flows have increased greatly, since the liberalization of international capital markets two decades ago (e.g., Lane and Milesi-Feretti (2003, 2005, 2006)). Equity home bias, while less severe than in earlier decades, remains sizable and is observed in all industrialized countries (see French and Poterba (1991) for early evidence and Sercu and Vanpée (2007) for a recent survey). There are broadly two classes of explanations for the persisting equity home bias. The first one centers on transaction costs and informational barriers in cross-border financial transactions and suggests that international risk sharing is insufficient. ${ }^{1}$ The second one focuses on the possibility that terms of trade changes in response to supply shocks may provide international insurance against these shocks, so that even a portfolio with home bias delivers efficient international risk sharing (Cole and Obstfeld (1991), Helpman and Razin (1978)).

Both types of explanations are helpful but are not without problems. Several authors have argued that frictions would have to be large to fully explain the equity home bias (French and Poterba (1991), Tesar and Werner (1995), Warnock (2002)). In order to interpret terms of trade changes as providing insurance (rather than a source of risk), the terms of trade would have to improve strongly after a negative supply shock. However, empirically the terms of trade are only weakly correlated with output (e.g., Backus, Kehoe and Kydland (1994)).

Using a two-country general equilibrium model with fully integrated financial markets, this paper shows that the interaction of the following ingredients is key for generating realistic equity home bias, without requiring strongly countercyclical terms of trade: capital accumulation and international trade in stocks and bonds denominated in local and foreign goods. ${ }^{2}$

By contrast, other recent general equilibrium models of international equity holdings (see Devereux and Sutherland (2006a,b) for references) have mostly assumed endowment economies, i.e. economies without production or capital accumulation - Heathcote and Perri (2007) is a notable exception discussed below. In such economies, households trade in international financial markets solely for consumption smoothing and risk sharing purposes so that the equity portfolio is structured to sustain net imports

\footnotetext{
${ }^{1}$ See, e.g., Heathcote and Perri (2002, 2004), Martin and Rey (2004), Coeurdacier and Guibaud (2008), Tille and van Wincoop (2007), and Van Nieuwerburgh and Veldkamp (2007) for recent studies on the role of frictions in international financial markets.

${ }^{2}$ Pavlova and Rigobon (2007a and b), Engel and Matsumoto (2006) and Coeurdacier, Kollmann and Martin (2007) have previously analyzed equity portfolio choice in general equilibrium models with trade in bonds.
} 
in states of nature where local production is low; this leads to local equity bias if relative Home equity returns rise (compared to Foreign returns) when the Home terms of trade improve and the Home real exchange rate appreciates, in response to a drop in the Home output. ${ }^{3}$ This condition however is not met in the data: empirically, the correlation between relative equity returns and the real exchange rate is low (van Wincoop and Warnock (2006)).

We consider a model with capital accumulation because, as discussed by Obstfeld and Rogoff (1996), one of the key functions of international financial markets is to finance physical investment; empirically, productive investment is a key driver of fluctuations in net imports (Sachs (1981), Backus, Kehoe and Kydland (1994)). With two stocks and two bonds, and two types of (Home and Foreign) technology shocks, markets are effectively complete, up to a first order (linear) approximation of the model. In addition to standard TFP (total factor productivity) shocks, the model here assumes shock to investment efficiency (as in Greenwood, Hercowitz and Krusell (1997, 2000), Fisher (2002, 2006)), because recent empirical research suggests that those shocks are an important source of fluctuations in real activity (Justiniano and Primiceri (2006), Justiniano et al. (2007)).

The equilibrium portfolio is structured to optimally hedge fluctuations in the real exchange rate and in labor incomes. ${ }^{4}$ Specifically, bonds are used for real exchange rate hedging, since the difference between the pay-offs of bonds denominated in Home and Foreign goods is correlated with the real exchange rate. Fluctuations in labor incomes are hedged through the equity portfolio. The key mechanism here is that fluctuations in investment generate a negative co-movement between Home capital income (net of investment) and Home labor income (relative to their Foreign counterparts). A Home investment boom lowers Home payments to shareholders (to finance investment) and raises Home output and wage incomes (relative to foreign wages), under the realistic assumption (made here) that there is a local bias in investment spending. Thus, local equity offers a good hedge against movements in local labor incomes associated with investment fluctuations - which explains why equilibrium equity portfolios exhibit home bias. The predicted equity home bias only depends on the degree of home bias in investment spending, and on the labor share. In particular, it is independent of preference parameters. ${ }^{5} \quad$ Importantly, the

\footnotetext{
${ }^{3}$ See Uppal (1993), Coeurdacier (2009), Kollmann (2006b).

${ }^{4}$ See Adler and Dumas (1983) for early work that stresses exchange rate hedging as a determinant of portfolio choice. Baxter and Jermann (1997), Heathcote and Perri (2007), Engel and Matsumoto (2006), Bottazzi, Pesenti and van Wincoop (1996), and Julliard (2002 and 2004), among others, discuss the hedging of labor income risk.

${ }^{5}$ Coeurdacier and Gourinchas (2008) provide a general discussion of the conditions under which equity portfolios are
} 
optimal portfolio does not hinge on the presence of investment efficiency shocks. These shocks help to explain the countercyclical nature of the trade balance and the acyclicality of the terms of trade but our portfolio results would also hold in a model with TFP shocks and a range of other (domestic and foreign) shocks to output and/or investment.

The closest paper to ours is Heathcote and Perri (2007) [HP henceforth] who were the first to investigate the importance of physical investment for equity portfolios. Trade in bonds, and the shocks to investment efficiency assumed here are the main difference between our model and HP. The HP model only generates realistic equity home bias if the terms of trade respond strongly to TFP shocks (or, equivalently, if preferences are "close enough" to log-separability between the two goods, as in a Cole and Obstfeld (1991) economy). Our model does not require strong terms of trade effects of productivity shocks - nevertheless, there is sizable equity home bias. This is important since the empirical evidence concerning the response of the terms of trade to technology shocks is mixed. ${ }^{6}$

Another paper close to ours is Engel and Matsumoto (2006) who analyze international equity portfolio choices in a model with money, sticky prices and trade in bonds, but without capital accumulation. Under price stickiness, the short run level of output is demand determined, so that a positive productivity shock leads to a fall in employment and labor income, but an increase in profits. Ownership of local equity is thus an effective hedge against labor income risk. In our model, local equity has a similar hedging property-but that property is driven by physical investment shocks (without requiring price stickiness).

A key contribution of the paper here is to explore the quantitative implications of the model regarding the dynamics of external asset positions and international capital flows. Gourinchas and Rey (2007), Tille (2005) and Lane and Milesi-Ferretti (2006) document empirically that fluctuations in the value of domestic and foreign assets induce external capital gains/losses that have a substantial effect on countries' net foreign asset positions (NFA). We show that the present model generates sizable international valuation effects. Here, fluctuations in a country's NFA are driven by asset price changes - NFA is thus predicted to have the time series properties of asset prices; in particular, the first difference of a country's NFA is predicted to be highly volatile and to have low serial correlation. We show that these predictions are independent of preference parameters.

${ }^{6}$ Corsetti, Dedola and Leduc (2008) argue that, empirically, a positive technology shocks triggers a terms of trade appreciation; Acemoglu and Ventura (2002) and Kollmann (2006c) provide evidence that higher productivity depreciates the terms-of-trade. 
consistent with the data. When there is a positive TFP or investment efficiency shock, net imports are predicted to rise on impact (due to a strong short run rise in investment), and to fall thereafter. As NFA equals the present value of current and future net imports, the NFA drops, on impact. Thus, the change in NFA is predicted to be countercyclical, which is likewise consistent with the data. Finally, the model generates sizable asset trades. ${ }^{7}$

We also show that our model has several interesting business cycle features. The investment efficiency shocks assumed here generate net exports and real exchange rate volatility that is larger-and thus closer to the data - than the volatility induced by TFP shocks. In the model here, a positive shock to a country's TFP raises that country's output while worsening its terms of trade; a country-specific shock to investment efficiency likewise raises output, but (on impact) it improves the terms of trade (the shock raises investment spending which is biased towards local inputs; hence it raises the relative price of those inputs). As a result, with the combined two types of shock, the terms of trade (and the real exchange rate) are less cyclical than in standard RBC models that are driven just by TFP shocks (e.g., Backus, Kehoe and Kydland (1994)). The presence of investment efficiency shocks also generates a cross-country correlation of consumption that is lower, and closer to the low correlations seen in the data. However, investment efficiency shocks generate cross-country correlations of investment, and within country correlations between investment and consumption that are too small when compared to the data. ${ }^{8}$

The paper is structured as follows. In section 2, we present the model set-up. In section 3 , we derive equilibrium equity and bond portfolios, and we provide empirical support for the key condition that drives equity home bias in the model. In section 4 , we provide stylized facts on the dynamics of external asset positions in G7 countries; we present simulation results that show that the model quantitatively captures key dynamic stylized facts.

\footnotetext{
${ }^{7}$ For other related recent empirical and theoretical analysis of international portfolios and external valuation effects, see e.g. Lewis (1999), Hau and Rey (2004), Siourounis (2004), Kraay et al. (2005), Devereux and Saito (2005), Ghironi, Lee and Rebucci (2005), Obstfeld (2006), Kollmann (2006a), and Matsumoto (2007). Evans and Hnatkovska (2005,2007) and Hnatkovska (2005) also discuss a world with capital accumulation and portfolios; those papers do not analyze the hedging logic that is central to our paper, and have a different empirical focus. Cantor and Mark (1988) provided an early theoretical discussion of the role of equity price changes for current accounts, based on a one-good model with equities trade (their model predicts full portfolio diversification).

${ }^{8}$ In simultaneous and independent work, Raffo (2008) also studies the effect of investment efficiency shocks on international business cycles.
} 


\section{The model}

There are two (ex-ante) symmetric countries, Home $(H)$ and Foreign $(F)$, each with a representative household. Country $i=H, F$ produces one good using labor and capital. There is trade in goods and in financial assets (stocks and bonds). All markets are perfectly competitive.

\subsection{Preferences}

Country $i$ is inhabited by a representative household who lives in periods $t=0,1,2, \ldots$. The household has the following life-time utility function:

$$
E_{0} \sum_{t=0}^{\infty} \beta^{t}\left(\frac{C_{i, t}^{1-\sigma}}{1-\sigma}-\frac{l_{i, t}^{1+\omega}}{1+\omega}\right),
$$

with $\omega>0 . C_{i, t}$ is $i$ 's aggregate consumption in period $t$ and $l_{i, t}$ is labor effort. Like much of the macroeconomics and finance literature, we take the coefficient of relative risk aversion to be greater than unity: $\sigma>1$.

$C_{i, t}$ is a composite good given by:

$$
C_{i, t}=\left[a^{1 / \phi}\left(c_{i, t}^{i}\right)^{(\phi-1) / \phi}+(1-a)^{1 / \phi}\left(c_{j, t}^{i}\right)^{(\phi-1) / \phi}\right]^{\phi /(\phi-1)}, \text { with } j \neq i,
$$

where $c_{j, t}^{i}$ is country $i$ 's consumption of the good produced by country $j$ at date $t . \phi>0$ is the elasticity of substitution between the two goods. In the (symmetric) deterministic steady state, $a$ is the share of consumption spending devoted to the local good. We assume a preference bias for local goods, $\frac{1}{2}<a<1$.

The welfare based consumer price index that corresponds to these preferences is:

$$
P_{i, t}=\left[a\left(p_{i, t}\right)^{1-\phi}+(1-a)\left(p_{j, t}\right)^{1-\phi}\right]^{1 /(1-\phi)}, j \neq i,
$$

where $p_{i, t}$ is the price of good $i$.

\subsection{Technologies and firms}

In period $t$, country $i$ produces $y_{i, t}$ units of good $i$ according to the production function

$$
y_{i, t}=\theta_{i, t}\left(k_{i, t}\right)^{\kappa}\left(l_{i, t}\right)^{1-\kappa},
$$


with $0<\kappa<1 . k_{i, t}$ is the country's stock of capital. Total factor productivity (TFP) $\theta_{i, t}>0$ is an exogenous random variable. The law of motion of the capital stock is:

$$
k_{i, t+1}=(1-\delta) k_{i, t}+\chi_{i, t} I_{i, t}
$$

where $0<\delta<1$ is the depreciation rate of capital. $I_{i, t}$ is gross investment in country $i$ at date $t . \chi_{i, t}>0$ is an exogenous shock to investment efficiency (see Fisher (2002, 2006), Greenwood, Hercowitz and Krusell (1997), Justiniano, Primiceri and Tambalotti (2007)). The stochastic properties of the exogenous shocks are symmetric across countries.

In both countries, gross investment is generated using Home and Foreign inputs:

$$
I_{i, t}=\left[a_{I}^{1 / \phi_{I}}\left(i_{i, t}^{i}\right)^{\left(\phi_{I}-1\right) / \phi_{I}}+\left(1-a_{I}\right)^{1 / \phi_{I}}\left(i_{j, t}^{i}\right)^{\left(\phi_{I}-1\right) / \phi_{I}}\right]^{\phi_{I} /\left(\phi_{I}-1\right)}, j \neq i
$$

where $i_{j, t}^{i}$ is the amount of good $j$ used for investment in country $i$. We assume a local bias in investment spending, $\frac{1}{2}<a_{I}<1$. Home bias and the substitution elasticity between domestic and imported inputs may be different for investment and consumption (i.e. we allow for the possibility that $a_{I} \neq a, \phi_{I} \neq \phi$ ). The associated investment price index is:

$$
P_{i, t}^{I}=\left[a_{I}\left(p_{i, t}\right)^{1-\phi_{I}}+\left(1-a_{I}\right)\left(p_{j, t}\right)^{1-\phi_{I}}\right]^{1 /\left(1-\phi_{I}\right)}, j \neq i .
$$

There is a (representative) firm in country $i$ that hires local labor, accumulates physical capital and produces output, using the technology $(4),(5)$; it maximizes the present value of dividend payments, taking prices and wage rates as given.

Due to the Cobb-Douglas technology, a share $1-\kappa$ of output is paid to workers. Thus, the country $i$ wage bill is:

$$
w_{i, t} l_{i, t}=(1-\kappa) p_{i, t} y_{i, t}
$$

where $p_{i, t}$ is the price of the country $i$ good and $w_{i, t}$ is the country $i$ wage rate.

For simplicity, we consider a baseline model specification in which investment is financed out of retained earning; a share $\kappa$ of the country's output, net of physical investment spending is thus paid out as a dividend $d_{i, t}$ to shareholders:

$$
d_{i, t}=\kappa p_{i, t} y_{i, t}-P_{i, t}^{I} I_{i, t}
$$


Below, we also discuss a model variant in which firms issue debt to finance investment spending; the household's equilibrium equity portfolio in that variant is the same as in the baseline specification.

The firm chooses $I_{i, t}$ to equate the expected future marginal gain of investment to the marginal cost. This implies the following first-order condition:

$$
1=E_{t} \varrho_{t, t+1}^{i} \frac{\chi_{i, t}}{P_{i, t}^{I}}\left[p_{i, t+1} \theta_{i, t+1} \kappa k_{i, t+1}^{\kappa-1} l_{i, t+1}^{1-\kappa}+(1-\delta) \frac{P_{i, t+1}^{I}}{\chi_{i, t+1}}\right]
$$

where $\varrho_{t, t+1}^{i} \equiv \beta\left(C_{i, t+1} / C_{i, t}\right)^{-\sigma}\left(P_{i, t} / P_{i, t+1}\right)$ is a pricing kernel used at date $t$ to value date $t+1$ payoffs. Note that we assume that $\varrho_{t, t+1}^{i}$ equals the intertemporal marginal rate of substitution of the country $i$ household. ${ }^{9}$ The firm chooses the Home and Foreign investment inputs $i_{H, t}^{i}, i_{F, t}^{i}$ that minimize the cost of generating $I_{i, t}$. That cost minimization problem has the following first-order conditions:

$$
i_{i, t}^{i}=a_{I}\left(\frac{p_{i, t}}{P_{i, t}^{I}}\right)^{-\phi_{I}} I_{i, t}, \quad i_{j, t}^{i}=\left(1-a_{I}\right)\left(\frac{p_{j, t}}{P_{i, t}^{I}}\right)^{-\phi_{I}} I_{i, t}, j \neq i .
$$

\subsection{Financial markets, household decisions, market clearing}

There is international trade in stocks and bonds. The country $i$ firm issues a stock that represents a claim to its stream of cash-flows $\left\{d_{i, t}\right\}$. The supply of each share is normalized at unity. There is a bond denominated in the Home good, and a bond denominated in the Foreign good; buying one unit of the Home (Foreign) bond in period $t$ gives one unit of the Home (Foreign) good in all future periods. Both bonds are in zero net supply. Each household fully owns the local stock, at birth, and has zero initial foreign assets. ${ }^{10} \quad$ Let $S_{j, t+1}^{i}$ denote the number of shares of stock $j$ held by the country $i$ household at the end of period $t$, while $b_{j, t+1}^{i}$ represents claims held by $i$ (at the end of $t$ ) to future unconditional payments of good $j$. At date $t$, the country $i$ household faces the following budget constraint:

$$
\begin{aligned}
& P_{i, t} C_{i, t}+p_{i, t}^{S} S_{i, t+1}^{i}+p_{j, t}^{S} S_{j, t+1}^{i}+p_{i, t}^{b} b_{i, t+1}^{i}+p_{j, t}^{b} b_{j, t+1}^{i} \\
= & w_{i, t} l_{i, t}+\left(p_{i, t}^{S}+d_{i, t}\right) S_{i, t}^{i}+\left(p_{j, t}^{S}+d_{j, t}\right) S_{j, t}^{i}+\left(p_{i, t}^{b}+p_{i, t}\right) b_{i, t}^{i}+\left(p_{j, t}^{b}+p_{j, t}\right) b_{j, t}^{i}, \quad j \neq i,
\end{aligned}
$$

\footnotetext{
${ }^{9}$ When the Home and Foreign households' Euler equations for Home/Foreign stocks shown below hold (see (14)), then (10) holds also for a pricing kernel that equals the intertemporal marginal rate of substitution of the country $j \neq i$ household.

${ }^{10} \mathrm{We}$ also assume that initial capital stocks and productivities are identical across countries: $K_{H, 0}=K_{F, 0}, \theta_{H, 0}=\theta_{F, 0}$, $\chi_{H, 0}=\chi_{F, 0}$. This ensures that both countries have equal wealth at birth, and preserves the (ex ante) symmetry of the two countries.
} 
where $p_{i, t}^{S}$ is the price of stock $i$ and $p_{i, t}^{b}$ is the price of the good- $i$ bond.

Each household selects portfolios, consumptions and labor supplies that maximize her life-time utility (1) subject to her budget constraint (12) for $t \geq 0$. Ruling out Ponzi-schemes, the following equations are first-order conditions of household $i$ 's decision problem:

$$
\begin{gathered}
c_{i, t}^{i}=a\left(\frac{p_{i, t}}{P_{i, t}}\right)^{-\phi} C_{i, t}, \quad c_{j, t}^{i}=(1-a)\left(\frac{p_{j, t}}{P_{i, t}}\right)^{-\phi} C_{i, t}, \quad l_{i, t}^{\omega}=\left(\frac{w_{i, t}}{P_{i, t}}\right) C_{i, t}{ }^{-\sigma} \\
1=E_{t} \varrho_{t, t+1}^{i} R_{j, t+1}^{S}, 1=E_{t} \varrho_{t, t+1}^{i} R_{j, t+1}^{b} \quad \text { for } j=H, F \\
\text { with } R_{j, t+1}^{S} \equiv \frac{p_{j, t+1}^{S}+d_{j, t+1}}{p_{j, t}^{S}}, \quad R_{j, t+1}^{b} \equiv \frac{p_{j, t+1}^{b}+p_{j, t+1}}{p_{j, t}^{b}} .
\end{gathered}
$$

$R_{j, t+1}^{S}$ and $R_{j, t+1}^{b}$ are the gross returns of stock $j$, and of the good- $j$ bond, respectively (between periods $t$ and $t+1)$. (13) represents the optimal allocation of consumption spending across goods, and the labor supply decision. (14) shows Euler equations with respect to the two stocks and the Home and Foreign good bonds.

Market-clearing in goods and asset markets requires:

$$
\begin{gathered}
c_{H, t}^{H}+c_{H, t}^{F}+i_{H, t}^{H}+i_{H, t}^{F}=y_{H, t}, \quad c_{F, t}^{F}+c_{F, t}^{H}+i_{F, t}^{F}+i_{F, t}^{H}=y_{F, t}, \\
S_{H, t}^{H}+S_{H, t}^{F}=S_{F, t}^{F}+S_{F, t}^{H}=1, \quad b_{H, t}^{H}+b_{H, t}^{F}=b_{F, t}^{F}+b_{F, t}^{H}=0 .
\end{gathered}
$$

\subsection{Relative consumption and investment demand}

Subsequent discussions will use the following properties of consumption and investment demand. The first-order condition for consumption (13) implies:

$$
c_{H, t}^{H}+c_{H, t}^{F}=p_{H, t}^{-\phi}\left[a C_{H, t} P_{H, t}^{\phi}+(1-a) C_{F, t} P_{F, t}^{\phi}\right], \quad c_{F, t}^{F}+c_{F, t}^{H}=p_{F, t}^{-\phi}\left[a C_{F, t} P_{F, t}^{\phi}+(1-a) C_{H, t} P_{H, t}^{\phi}\right]
$$

Taking the ratio of these expressions gives:

$$
y_{C, t} \equiv \frac{c_{H, t}^{H}+c_{H, t}^{F}}{c_{F, t}^{F}+c_{F, t}^{H}}=q_{t}^{-\phi} \Omega_{a}\left[\left(\frac{P_{F, t}}{P_{H, t}}\right)^{\phi} \frac{C_{F, t}}{C_{H, t}}\right], \quad \text { with } \quad \Omega_{z}(x) \equiv \frac{1+x\left(\frac{1-z}{z}\right)}{x+\left(\frac{1-z}{z}\right)} .
$$

$y_{C, t}$ is the ratio of world consumption of Home goods over world consumption of Foreign goods, while $q_{t} \equiv p_{H, t} / p_{F, t}$ denotes the country $\mathrm{H}$ terms of trade. 
The ratio of world demand for Home vs. Foreign goods used for physical investment $y_{I, t} \equiv \frac{i_{H, t}^{H}+i_{H, t}^{F}}{i_{F, t}^{F}+i_{F, t}^{H}}$ can similarly be expressed as:

$$
y_{I, t} \equiv q_{t}^{-\phi_{I}} \Omega_{a_{I}}\left[\left(\frac{P_{F, t}^{I}}{P_{H, t}^{I}}\right)^{\phi_{I}} \frac{I_{F, t}}{I_{H, t}}\right] .
$$

\section{Characterization of (steady state) equilibrium portfolios}

Equilibrium portfolio holdings chosen at date $t\left(S_{i, t+1}^{i}, S_{j, t+1}^{i}, b_{i, t+1}^{i}, b_{j, t+1}^{i}\right)$ are functions of predetermined state variables, and of exogenous shocks at $t$. Devereux and Sutherland $(2006 \mathrm{a}, \mathrm{b})$ show how to compute Taylor expansion of the portfolio decision rules, in the neighborhood of the deterministic steady state. In this Section, we provide closed form solutions for the Home/Foreign 'zero-order portfolio' (denoted by variables without time subscripts) $S_{i}^{i}, S_{j}^{i}, b_{i}^{i}, b_{j}^{i}$, i.e. portfolio decision rules evaluated at steady state values of state variables. That portfolio can be determined by linearizing the model around its steady state. ${ }^{11}$

\subsection{Linearization of the model}

Henceforth, variables without a time subscript refer to the steady state. $\widehat{z_{t}} \equiv\left(z_{t}-z\right) / z$ denotes the relative deviation of a variable $z_{t}$ from its steady state value $z$.

Below we find a zero-order portfolio such that the ratio of Home to Foreign marginal utilities of aggregate consumption, $C_{H, t}^{-\sigma} / C_{F, t}^{-\sigma}$, is equated to the consumption-based real exchange rate, $R E R_{t} \equiv$ $\frac{P_{H, t}}{P_{F, t}}$, up to first order:

$$
-\sigma\left(\widehat{C_{H, t}}-\widehat{C_{F, t}}\right)=\widehat{R E R_{t}}
$$

This is a linearized version of a risk sharing condition that holds under complete markets (Backus and Smith (1993), Kollmann $(1991,1995))$. Up to first order, the asset structure here (four assets, in a

\footnotetext{
${ }^{11}$ Devereux and Sutherland (2006a,b) show that the zero-order equilibrium portfolio has to satisfy a second-order accurate approximation of household Euler equations, expressed in 'relative' form: $0=E_{t} \varrho_{t, t+1} r_{t+1}^{X}$, where $\varrho_{t, t+1} \equiv \varrho_{t, t+1}^{H}-\varrho_{t, t+1}^{F}$ is the 'relative' IMRS of the two households, while $r_{t+1}^{X} \equiv\left(R_{H, t+1}^{S}-R_{H, t+1}^{b}, R_{F, t+1}^{S}-R_{H, t+1}^{b}, R_{F, t+1}^{b}-R_{H, t+1}^{b}\right)$ is a vector of excess returns. As $\varrho=r^{X}=0$ in steady state, a second-order accurate approximation is given by $0=E_{t}\left(\varrho_{t, t+1}\right)^{(1)}\left(r_{t+1}^{X}\right)^{(1)}$, where $\left(\varrho_{t, t+1}\right)^{(1)}$ and $\left(r_{t+1}^{X}\right)^{(1)}$ are first-order accurate. The zero-order portfolio discusses below satisfies a linearized risk sharing condition (see $(20))$ that entails that $\left(\varrho_{t, t+1}\right)^{(1)}=0$; thus, the zero-order portfolio discussed below ensures that $0=E_{t} \varrho_{t, t+1} r_{t+1}^{X}$ holds to second-order.
} 
world with four exogenous shocks) is thus (effectively) complete. ${ }^{12}$

It follows from the definition of Home and Foreign CPI indices (see (3)) that

$$
\widehat{R E R_{t}}=\widehat{P_{H, t}}-\widehat{P_{F, t}}=(2 a-1) \widehat{q_{t}} .
$$

Due to consumption home bias $\left(a>\frac{1}{2}\right)$, an improvement of the Home terms of trade generates an appreciation of the Home real exchange rate.

When (20) holds, then the relative world consumption demand for the Home good obeys (from (18)):

$$
\widehat{y_{C, t}}=-\left[\phi\left(1-(2 a-1)^{2}\right)+(2 a-1)^{2} \frac{1}{\sigma}\right] \widehat{q_{t}} \equiv-\lambda \widehat{q_{t}}
$$

where $\lambda \equiv \phi\left(1-(2 a-1)^{2}\right)+\frac{(2 a-1)^{2}}{\sigma}$. Note that $\lambda>0 \quad\left(\right.$ as $1 / 2<a<1$ implies $\left.0<1-(2 a-1)^{2}\right)$. Thus, an improvement in the Home terms of trade lowers worldwide relative consumption of the Home good.

Linearization of (19) and (7) shows that relative world investment demand for the Home good, $y_{I, t}$, obeys:

$$
\widehat{y_{I, t}}=-\phi_{I}\left(1-\left(2 a_{I}-1\right)^{2}\right) \widehat{q_{t}}+\left(2 a_{I}-1\right) \widehat{I}_{t},
$$

where $I_{t} \equiv I_{H, t} / I_{F, t}$ is relative real aggregate investment. Holding constant the terms of trade, the relative demand for Home investment goods, $y_{I, t}$, increases with relative real investment in the Home country, $I_{t}$, since Home aggregate investment is biased towards the Home good $\left(a_{I}>\frac{1}{2}\right)$.

The market clearing condition for goods (16) implies:

$$
(1-\Lambda) \widehat{y_{C, t}}+\Lambda \widehat{y_{I, t}}=\widehat{y_{t}}
$$

where $y_{t} \equiv Y_{H, t} / Y_{F, t}$ is relative Home output, while $\Lambda \equiv \frac{P_{H}^{I} I_{H}}{p_{H} y_{H}}=\frac{P_{F}^{I} I_{F}}{p_{F} y_{F}}$ is the steady state investment/GDP ratio. ${ }^{13}$

Substituting (22) and (23) into (24) gives:

$$
\widehat{y_{t}}=-\lambda^{*} \widehat{q_{t}}+\Lambda\left(2 a_{I}-1\right) \widehat{I_{t}}
$$

\footnotetext{
${ }^{12}$ Using the apparatus of Devereux and Sutherland (2006a,b) we confirmed for the model calibration below (and for all of many other calibrations with which we experimented) that the zero-order equilibrium portfolio is unique; there is no zero-order equilibrium portfolio for which the risk sharing condition (20) does not hold, to first order.

${ }^{13}$ Note that, because of symmetry, $P_{H}^{I} / p_{H}=P_{F}^{I} / p_{F}=1, I_{H}=I_{F}, y_{H}=y_{F}$.
} 
where $\lambda^{*}=(1-\Lambda) \lambda+\Lambda \phi_{I}\left(1-\left(2 a_{I}-1\right)^{2}\right)>0 . \quad 14$

Not surprisingly, Home terms of trade worsen when the relative supply of Home goods increases, for a given amount of relative Home country investment. Home terms of trade improve when Home investment rises (due to local bias in investment spending), for a given value of the relative Home/Foreign output.

\subsection{Zero-order portfolios}

Ex-ante symmetry implies that the zero-order portfolios have to satisfy these conditions: $S \equiv S_{H}^{H}=$ $S_{F}^{F}=1-S_{H}^{F}=1-S_{F}^{H} ; \quad b \equiv b_{H}^{H}=b_{F}^{F}=-b_{H}^{F}=-b_{F}^{H}$. The pair $(S, b)$ thus describes the (zero-order) equilibrium portfolio. Note that $S$ denotes a country's holdings of local stock, while $b$ denotes its holdings of bonds denominated in the local good. There is equity home bias when $S>\frac{1}{2}$. $b>0$ means that a country is long in local-good bonds (and short in foreign-good bonds).

We now show that there exists a unique portfolio $(S, b)$ that satisfies the following 'static' budget constraint, for consumptions that are consistent with the linearized risk sharing condition (20):

$$
P_{i, t} C_{i, t}=w_{i, t} l_{i, t}+S d_{i, t}+(1-S) d_{j, t}+b\left(p_{i, t}-p_{j, t}\right), \text { for } i=H, F
$$

According to this constraint, country $i$ consumption spending at date $t$ equals date $t$ wage income, $w_{i, t} l_{i, t}$, plus the financial income generated by the zero-order portfolio $(S, b)$. We show in a Technical Appendix (posted on the corresponding author's web page) that when this 'static' budget constraint holds, then the period-by-period budget constraint (12) is likewise satisfied, up to first-order. We here focus on the 'static' budget constraint, as it greatly simplifies the analysis.

Subtracting the 'static' budget constraint of country $F$ from that of country $H$ gives:

$$
P_{H, t} C_{H, t}-P_{F, t} C_{F, t}=\left(w_{H, t} l_{H, t}-w_{F, t} l_{F, t}\right)+(2 S-1)\left(d_{H, t}-d_{F, t}\right)+2 b\left(p_{H, t}-p_{F, t}\right)
$$

Linearizing this yields:

$$
(1-\Lambda)\left(\widehat{P_{H, t} C_{H, t}}-\widehat{P_{F, t} C_{F, t}}\right)=(1-\Lambda)\left(1-\frac{1}{\sigma}\right) \underbrace{(2 a-1) \widehat{q_{t}}}_{\widehat{R E R_{t}}}=(1-\kappa) \widehat{w_{t} l_{t}}+(2 S-1)(\kappa-\Lambda) \widehat{d_{t}}+2 \widetilde{b} \widehat{q}_{t}, \quad \widetilde{b} \equiv b / y_{H},
$$

\footnotetext{
${ }^{14}$ When $\phi_{I}=\phi$ and $a_{I}=a$ then $\lambda^{*}=\phi\left(1-(2 a-1)^{2}\right)+\frac{1-\Lambda}{\sigma}(2 a-1)^{2}$.
} 
where $\widehat{w_{t} l_{t}} \equiv \widehat{w_{H, t} l_{H, t}}-\widehat{w_{F, t} l_{F, t}}$ denotes relative Home labor income, while $\widehat{d_{t}} \equiv \widehat{d_{H, t}}-\widehat{d_{F, t}}$ is the relative Home dividend, and $\widetilde{b}$ represents holdings of local-good bonds, divided by steady state GDP.

The first equality in (28) follows from the linearized risk-sharing condition (20); it shows the efficient reaction of relative consumption spending to a change of the welfare based real exchange rate. This reaction depends on the coefficient of relative risk aversion. A shock that appreciates the real exchange rate of country $H$, induces an increase in country $H$ relative consumption spending when $\sigma>1$ (as assumed here). (20) shows that when the Home real exchange rate appreciates by $1 \%$, then relative aggregate country $H$ consumption $\left(\frac{C_{H}}{C_{F}}\right)$ decreases by $1 / \sigma \%$. Hence, relative country $H$ consumption spending $\left(\frac{P_{H} C_{H}}{P_{F} C_{F}}\right)$ increases by $\left(1-\frac{1}{\sigma}\right) \%$.

The expression to the right in (28) shows the change in country $H$ income (relative to the income of $F$ ) necessary to finance the efficient consumption (up to first order). Given $\sigma>1$, the efficient portfolio has to be such that a real appreciation is associated with an increase in relative Home income.

Since labor income is a constant share of output (see $(8))$, relative labor income $\left(\widehat{w}_{t} l_{t}\right)$ is given by: $\widehat{w_{t} l_{t}}=\widehat{q_{t}}+\widehat{y_{t}}$. (9) and (7) imply that the relative dividend $\left(\widehat{d}_{t}\right)$ is given by:

$$
(\kappa-\Lambda) \widehat{d_{t}}=\kappa\left(\widehat{q_{t}}+\widehat{y_{t}}\right)-\Lambda\left(\widehat{P_{H, t}^{I} I_{H, t}}-\widehat{P_{F, t}^{I} I_{F, t}}\right)=\kappa\left(\widehat{q_{t}}+\widehat{y_{t}}\right)-\Lambda\left(\left(2 a_{I}-1\right) \widehat{q_{t}}+\widehat{I_{t}}\right) .
$$

Substituting (29) into (28) gives:

$$
(1-\Lambda)\left(1-\frac{1}{\sigma}\right)(2 a-1) \widehat{q_{t}}=(1-\kappa)\left(\widehat{q_{t}}+\widehat{y_{t}}\right)+(2 S-1)\left\{\kappa\left(\widehat{q_{t}}+\widehat{y_{t}}\right)-\Lambda\left(\left(2 a_{I}-1\right) \widehat{q_{t}}+\widehat{I_{t}}\right)\right\}+2 \widetilde{b} \widehat{q_{t}}
$$

Using (25), we can express (30) as:

$$
(1-\Lambda)\left(1-\frac{1}{\sigma}\right)(2 a-1) \widehat{q_{t}}=[(1-\kappa)+\kappa(2 S-1)]\left(\left(1-\lambda^{*}\right) \widehat{q}_{t}+\Lambda\left(2 a_{I}-1\right) \widehat{I}_{t}\right)-\Lambda(2 S-1)\left[\left(2 a_{I}-1\right) \widehat{q_{t}}+\widehat{I_{t}}\right]+2 \widetilde{b} \widehat{q}_{t}
$$

The asset structure supports the full risk sharing condition (20), up to first-order, if (31) holds for all realizations of the two (relative) exogenous shocks $\left(\widehat{\theta}_{t}, \widehat{\chi_{t}}\right)$. The following portfolio $(S, \widetilde{b})$ ensures that (31) holds for arbitrary realizations of $\left(\widehat{q_{t}}, \widehat{I}_{t}\right)$ :

$$
\begin{aligned}
S & =\frac{1}{2}\left[1+\frac{\left(2 a_{I}-1\right)(1-\kappa)}{1-\left(2 a_{I}-1\right) \kappa}\right]>\frac{1}{2} \\
\widetilde{b} & =\frac{1}{2}\left[(1-\Lambda)\left(1-\frac{1}{\sigma}\right)(2 a-1)+\frac{(1-\kappa)\left[\lambda^{*}-1+\Lambda\left(2 a_{I}-1\right)^{2}\right]}{1-\left(2 a_{I}-1\right) \kappa}\right]
\end{aligned}
$$


Thus, the model generates equity home bias: $1 / 2<S<1$. Interestingly, the equity portfolio is independent of preference parameters; in particular, $S$ is independent of the substitution elasticity between Home and Foreign goods, and thus of the strength of the response of the terms of trade to shocks. ${ }^{15}$ The equity portfolio solely depends on the local bias in investment spending $\left(a_{I}\right)$ and on the capital share $(\kappa)$; equity home bias is increasing in the local spending bias-this prediction is strongly supported by the data (see Heathcote and Perri (2007) and Collard, Dellas, Diba and Stockman (2007)).

The persistence of shocks and their correlation do not matter for the (zero-order) equilibrium portfolio (as long as the shocks are not perfectly correlated). Note that, to solve for the equilibrium portfolio, we do not have to solve for output and investment, as a unique pair of terms of trade and relative real investment $\left(\widehat{q}_{t}, \widehat{I}_{t}\right)$ is associated with each realizations of $\left(\widehat{\theta}_{t}, \widehat{\chi}_{t}\right)$. In fact, any other combinations of two types of relative (Home vs. Foreign) shocks that only affect the (linearized) relative budget constraint through their effect on the terms of trade and relative investment generates the same equilibrium portfolio - other potential shocks that would generate the same portfolio are e.g. labor supply shocks, "news" shocks regarding future TFP or investment efficiency, and shocks to the depreciation rate of capital.

Note also that, in contrast to the setting here (with trade in stocks and bonds), general equilibrium models with just trade in stocks (no bonds) predict that the equity portfolio exhibits strong sensitivity with respect to the substitution elasticity between local and imported goods (e.g., Kollmann (2006b), Coeurdacier (2009) and Heathcote and Perri (2007)). ${ }^{16}$

In the model here, the bond portfolio does depend on the substitution elasticities $\phi, \phi_{I}\left(\operatorname{via} \lambda^{*}\right)$ and on risk aversion $(\sigma)$; however this dependence is 'smooth': in particular, the net local-good bond position $\widetilde{b}$ is a linear function of $\phi$ and $\phi_{I} \cdot{ }^{17}$ Depending on preference parameters, the model can generate a positive or negative value of $\widetilde{b}$. The country will go short in the local-good bond $(\widetilde{b}<0)$ when $\phi$ is sufficiently low (roughly below unity). When $\phi$ is low, then the terms of trade respond strongly to shocks; an improvement in the Home terms of trade (induced by a fall in Home TFP and/or an increase in Home investment efficiency) increases Home relative wage plus dividend income (due to the strong terms of

\footnotetext{
${ }^{15}$ However it is necessary that good are imperfect substitutes so that the terms of trade show a non-zero response to shocks.

${ }^{16}$ In those models, the asset structure cannot support the efficient allocation when Home and Foreign dividends are colinear, which occurs for a value of the substitution elasticity roughly located between 1 and 2 ; for substitution elasticities just below or above the critical value, the local equity share takes extremely large positive or negative values.

${ }^{17}$ See Coeurdacier, Kollmann and Martin (2007) and Coeurdacier and Gourinchas (2008) for a similar result.
} 
trade change); risk sharing requires to compensate this relative income effect by shorting the local good

bond (when $\widetilde{b}<0$, a terms of trade improvement lowers the net bond income received by Home). By contrast, the country goes long in the local good bond, and short in the foreign good bond, when $\phi$ is (roughly) greater than unity.

Recent empirical research (Lane and Shambaugh (2007, 2008)) shows that, on average, the advanced countries have negative net foreign-currency debt positions - which is consistent with our model for values of $\phi$ above unity. However, there is a great deal of cross-country heterogeneity in net foreign/domestic currency debt positions. While net debt positions are small for most advanced countries, some major countries have large negative net domestic-currency debt positions; most notably this is the case for the US. In our theoretical framework, negative net local-good debt positions obtain for a wider range of parameters, if one allows for corporate debt (see below). Finally, one should note that countries can easily alter the effective currency composition of their debt portfolio by taking net positions in the forward currency market; this further complicates the comparison of our theoretical bond positions with their empirical counterparts.

\section{Debt and Equity Financing}

We have assumed so far that firms are fully financed through equity, and that investment is fully financed through retained earnings. In the Technical Appendix, we discuss a model variant in which firms are partly financed through debt. Since the Modigliani-Miller theorem applies in the structure here, corporate debt does not affect the value of firms, physical investment and the equilibrium consumption allocation. As shown in the Technical Appendix, the equilibrium equity portfolio is likewise unaffected by the presence of corporate bonds (i.e. S continues to be given by (32)). The country i household holds a fraction $\mathrm{S}$ of the corporate debt issued by the local firm, in order to offset the implicit debt position entailed by the household's local equity position; thus households exhibit home bias for corporate debt, in the same proportion as for stocks. If firms mainly issue local-good debt, this lowers the countries' overall (household+corporate) net local-good bond position: when the local firm issues one unit of debt denominated in the local good, then the overall net local debt position changes by $\mathrm{S}-1<0$ units, as a share $\mathrm{S}$ of the new debt will be purchased by the local household, while a share $1-\mathrm{S}$ will be bought by the foreign household. 


\section{The hedging roles of bonds and stocks}

We now show that the bond portfolio hedges terms of trade (real exchange rate) risk - as preference parameters affect the response of relative consumption to terms of trade changes, bond holdings depend on those preference parameters. Equities are used to hedge fluctuations in relative wages and dividends that are orthogonal to the terms of trade. The comovement of relative wages and dividends, at constant terms of trade, depends on $a_{I}$ and $\kappa$, but not on preference parameters - which explains why the equilibrium value of $S$ is a function of $a_{I}$ and $\kappa .{ }^{18}$

Assume a combination of exogenous shocks $\left(\widehat{\theta}_{t}, \widehat{\chi}_{t}\right)$ that raises relative country $H$ real investment spending, without altering the terms of trade: $\widehat{I_{t}}>0, \widehat{q_{t}}=0$. From (25), we know that this combination of shocks raises $H$ relative output $\widehat{y_{t}}$, due to local bias in investment spending $\left(a_{I}>1 / 2\right)$ : $\widehat{y_{t}}=$ $\Lambda\left(2 a_{I}-1\right) \widehat{I}_{t}>0$, when $\widehat{q_{t}}=0$. As the real exchange rate is unaffected when $\widehat{q_{t}}=0$ (see (21)), efficient risk sharing requires that countries' relative consumption spending remains unchanged. Hence, the efficient portfolio has to be such that the countries' relative income too is unaffected. From (30) it can be seen that this requires that:

$$
0=(1-\kappa) \widehat{y_{t}}+(2 S-1)\left\{\kappa \widehat{y_{t}}-\Lambda \widehat{I_{t}}\right\}
$$

$(1-\kappa) \widehat{y_{t}}$ and $\left\{\kappa \widehat{y_{t}}-\Lambda \widehat{I}_{t}\right\}$ respectively represent relative labor income of country $H$ and the relative dividend of stock $H$, for $\widehat{q_{t}}=0$. Note that $\kappa \widehat{y}_{t}-\Lambda \widehat{I}_{t}=\left[\kappa\left(2 a_{I}-1\right)-1\right] \Lambda \widehat{I}_{t}$ when $\widehat{y_{t}}=\Lambda\left(2 a_{I}-1\right) \widehat{I}_{t}$. Thus, $\kappa \widehat{y}_{t}-\Lambda \widehat{I}_{t}<0$ when $\widehat{I}_{t}>0, \widehat{q_{t}}=0$. In other terms, a combination of shocks that raises $H$ relative investment without affecting the terms of trade induces a rise in $H$ 's relative wage income, and a fall in the relative dividend of stock $H$. This makes holding local equity attractive: $S>1 / 2$ is needed to ensure that (34) holds. ${ }^{19}$

Once shocks that do not affect the terms of trade have been hedged by holding local equity, the remaining risk (changes in output/investment that are associated with terms of trade changes) can be hedged (up to a linear approximation) using the bond portfolio; this is so because terms of trade movements are perfectly correlated with the difference between the pay-offs of Home and Foreign good bonds.

\footnotetext{
${ }^{18}$ Coeurdacier and Gourinchas (2008) provide a general discussion of conditions under which international equity portfolios are independent of preferences; they show that an important condition is that bonds exist whose pay-offs perfectly track real exchange rate movements.

${ }^{19}$ To derive the value of S shown in (32), one can substitute $\widehat{y_{t}}=\Lambda\left(2 a_{I}-1\right) \widehat{I_{t}}$ into (34); the only value of $S$ for which the resulting expression holds for arbitrary $\widehat{I_{t}}$ is given by (32).
} 


\section{Comparison with Heathcote and Perri (2007)}

Our equity portfolio (32) corresponds to that obtained by Heathcote and Perri (2007) [HP], for a special case of their model with a unit risk aversion coefficient $(\sigma=1)$ and a unit elasticity of substitution between domestic and foreign good $(\phi=1)$. HP assume a two-country world with capital accumulation, with just trade in stocks (no bonds), and just TFP shocks. In their model, the equity portfolio is sensitive to slight changes in $\sigma$ and $\phi$; extreme home or foreign equity bias occurs for values of $\sigma$ and $\phi$ in a plausible range above unity. ${ }^{20}$

Here we have shown that this sensitivity of portfolio choices disappears once we allow for trade in bonds, and an additional source of uncertainty on the production side (here shock to investment efficiency). This robustness is due to the fact that, in our model, terms of trade risk is hedged by the bond portfolio. This result is important, as there is considerable uncertainty regarding the value of the substitution elasticity between domestic and foreign goods: estimates from aggregate macro data are scattered around unity, but estimates from sectoral trade data are above 4 (see Imbs and Méjean (2008) for a detailed discussion).

The reason why the HP model delivers equity home bias when $\sigma=\phi=1$ is that, for that parametrization, the two countries' efficient relative consumption spending is constant, while a country's relative wage income is (perfectly) negatively correlated with the relative dividend of the stock issued by the country $\left(\operatorname{Corr}\left(\widehat{w_{t} l_{t}}, \widehat{d}_{t}\right)<0\right)$, which implies that local equity is a good hedge for labor income risk. As documented below, the correlation between relative wage income $\left({\widehat{w_{t} l_{t}}}\right)$ and the relative dividend $\left(\widehat{d}_{t}\right)$ is positive, for G7 countries. Thus, the key mechanism that generates equity home bias in the HP model is rejected empirically.

\subsection{The role of the correlation between relative wage incomes and relative 'dividends'}

In our model, the unconditional correlation $\operatorname{Corr}\left(\widehat{w_{t} l_{t}}, \widehat{d}_{t}\right)$ per se is irrelevant for the equilibrium equity portfolio. What matters is the correlation between the components of $\widehat{w_{t} l_{t}}$ and $\widehat{d_{t}}$ that are orthogonal to the terms of trade, $\widehat{q_{t}}$ : there is equity home bias when that correlation is negative. To see this, project

\footnotetext{
${ }^{20}$ Castello (2007) considers a model of portfolio choice with capital accumulation close to HP; in her model too, equity portfolios are highly sensitive to preference parameters.
} 
equation $(28)$ on $\widehat{q_{t}}$. This gives:

$$
(1-\Lambda)\left(1-\frac{1}{\sigma}\right)(2 a-1) \widehat{q_{t}}=(1-\kappa) P\left[\widehat{w_{t} l_{t}} \mid \widehat{q}_{t}\right]+(2 S-1)(\kappa-\Lambda) P\left[\widehat{d}_{t} \mid \widehat{q_{t}}\right]+2 \widetilde{b} \widehat{q_{t}},
$$

where $P\left[\widehat{w_{t} l_{t}} \mid \widehat{q_{t}}\right]$ is the (linear) projection of $\widehat{w_{t} l_{t}}$ on $\widehat{q_{t}}$. (NB $\left.\widehat{q_{t}}=P\left[\widehat{q}_{t} \mid \widehat{q}_{t}\right].\right)$ Subtracting (35) from (28) gives:

$$
0=(1-\kappa)\left\{\widehat{w_{t} l_{t}}-P\left[\widehat{w_{t} l_{t}} \mid \widehat{q_{t}}\right]\right\}+(2 S-1)(\kappa-\Lambda)\left\{\widehat{d_{t}}-P\left[\widehat{d}_{t} \mid \widehat{q_{t}}\right]\right\}
$$

Thus, the equity portfolio has to hedge the components of $\widehat{w_{t} l_{t}}$ and $\widehat{d_{t}}$ that are orthogonal to the terms of trade $\widehat{q_{t}}$. (36) implies that

$$
S=\frac{1}{2}-\frac{1}{2} \frac{1-\kappa}{\kappa-\Lambda} \frac{\operatorname{Cov}_{\widehat{q}}\left(\widehat{w}_{t} l_{t}\right.}{\left.\operatorname{dar}_{t}\right)},
$$

with $\operatorname{Cov}_{\widehat{q}}\left(\widehat{w_{t} l_{t}}, \widehat{d}_{t}\right) \equiv E\left\{\widehat{w_{t} l_{t}}-P\left[\widehat{w_{t} l_{t}} \mid \widehat{q}_{t}\right]\right\}\left\{\widehat{d}_{t}-P\left[\widehat{d}_{t} \mid \widehat{q}_{t}\right\}, \operatorname{Var}_{\widehat{q}}\left(\widehat{d}_{t}\right) \equiv E\left\{\widehat{d}_{t}-P\left[\widehat{d}_{t} \mid \widehat{q}_{t}\right]\right\}^{2}\right.$. ${ }^{21} \quad$ Hence there is equity home bias if and only if $\operatorname{Cov}_{\widehat{q}}\left(\widehat{w_{t} l_{t}}, \widehat{d}_{t}\right)<0 .{ }^{22}$ In the model here, $\operatorname{Cov}_{\widehat{q}}\left(\widehat{w_{t} l_{t}}, \widehat{d}_{t}\right)=$ $(\kappa-\Lambda)\left(2 a_{I}-1\right) /\left[\left(\kappa\left(2 a_{I}-1\right)-1\right)\right]<0$. Empirically, $\operatorname{Cov}_{\widehat{q}}\left(\widehat{w_{t} l_{t}}, \widehat{d}_{t}\right)<0$, for G7 countries, as documented below.

A similar condition is derived by Engel and Matsumoto (2006) who show, in a model with trade in equity and nominal forward currency contracts, that the equilibrium equity position depends on the conditional covariance between wage income and dividends, conditional on the nominal exchange rate.

Note also that $(1-\kappa) P\left[\widehat{w_{t} l_{t}} \mid \widehat{q}_{t}\right]+(2 S-1)(\kappa-\Lambda) P\left[\widehat{d}_{t} \mid \widehat{q}_{t}\right]=\gamma \widehat{q_{t}}$ for some coefficient $\gamma$. Hence, (35) can be expressed as: $(1-\Lambda)\left(1-\frac{1}{\sigma}\right)(2 a-1) \widehat{q_{t}}=\gamma \widehat{q_{t}}+2 \widetilde{b} \widehat{q_{t}}$. The bond position is set at the value for which this condition holds for any realization of $\widehat{q_{t}}: \widetilde{b}=\frac{1}{2}\left[(1-\Lambda)\left(1-\frac{1}{\sigma}\right)(2 a-1)-\gamma\right]$. Thus, the optimal bond position ensures that terms of trade fluctuations induce movements in the two countries' relative incomes (given the optimal equity portfolio) that track optimal relative consumption spending. For this to be the case, relative bond payments need to track the real exchange rate. In the data, domesticversus foreign-currency bond return differentials are tightly linked to real exchange rate changes (see Coeurdacier and Gourinchas (2009) and van Wincoop and Warnock (2006)).

\section{Equilibrium equity portfolios for countries of different size}

In order to permit empirical analysis of the determinants of equity home bias, we now briefly consider a two-country model with countries of unequal size, due to different steady state TFP (and/or population).

\footnotetext{
${ }^{21}$ To see this, multiply (36) by $\left\{\widehat{d}_{t}-P\left[\widehat{d_{t}} \mid \widehat{q_{t}}\right]\right\}$ and take expectations; solving the resulting equation for $S$ gives (37).

${ }^{22}$ The steady state investment/GDP ratio is $\Lambda=\kappa /[(1 / \delta)(1-\beta) / \beta+1]$. Hence, $\kappa>\Lambda$. This ensures that dividends are strictly positive in steady state.
} 
Assume that all preference and technology parameters are the same across countries. Then $S_{i}^{i}$ is given by:

$$
S_{i}^{i}=\mu_{i}-\left(1-\mu_{i}\right) \frac{1-\kappa}{\kappa-\Lambda} \frac{\operatorname{Cov}_{\widehat{q}}\left(\widehat{w_{t} l_{t}}, \widehat{d}_{t}\right)}{\operatorname{Var}_{\widehat{q}}\left(\widehat{d}_{t}\right)} .
$$

were $\mu_{i} \equiv p_{i} y_{i} /\left(p_{H} y_{H}+p_{F} y_{F}\right)$ is the (steady state) share of country i's GDP in world GDP. ${ }^{23}$ Again, there is equity home bias $\left(S_{i}^{i}>\mu_{i}\right)$ when $\operatorname{Cov}_{\widehat{q}}\left(\widehat{w_{t} l_{t}}, \widehat{d}_{t}\right)<0$. We now show that this condition holds empirically.

\section{Empirical evidence on the correlation between relative wage income and relative 'divi-} dends' in G7 countries

For each G7 country, we obtained annual time series on aggregate nominal wage incomes of domestic households, and on profits of domestic firms. ${ }^{24}$ An empirical counterpart to the 'dividend' of the country $i$ firm $d_{i}$ is constructed by subtracting gross investment spending from profits. Note that the series computed this way correspond exactly to the 'dividends' assumed in the model. This variable obviously differ from actual dividends, in a world in which firms issue debt to finance investment. However this is the relevant measure for testing the theory, as dividend policy has no impact on equity portfolios in our framework, because the Modigliani-Miller theorem holds here.

We divide each country's nominal wage income (dividend) by total wage income (dividend) in the remaining G7 countries (using nominal exchange rates). We log and linearly de-trend the resulting series to construct the relative wage income and dividend variables ${\widehat{w_{t} l_{t}}}_{\text {and }} \widehat{d}_{t}$. All series are annual and pertain to 1984-2004. Unconditional empirical correlations $\operatorname{Corr}\left(\widehat{w_{t} l_{t}}, \widehat{d}_{t}\right)$ are given in Panel (a) of Table 1. For six of the G7 countries $\operatorname{Corr}\left(\widehat{w_{t} l_{t}}, \widehat{d}_{t}\right)$ is positive, and significantly different from zero

\section{[INSERT TABLE 1 ABOUT HERE]}

Panels (b) and (c) of Table 1 shows estimates of the conditional correlation $\operatorname{Corr}_{\widehat{q}}\left(\widehat{w_{t} l_{t}}, \widehat{d}_{t}\right)$. In the model, the terms of trade correspond to the relative price of Home-produced and Foreign-produced goods. We consider two empirical measures of the country $i$ terms of trade: the first measure is the ratios of $i$ 's GDP deflator to a geometric weighted average (based on GDP weights) of the GDP deflators of the remaining G7 countries (expressed in country $i$ currency using nominal exchange rates); the second

\footnotetext{
${ }^{23}$ When $\kappa, \delta, \beta$ are identical across countries, then the steady state investment spending/GDP ratio $\Lambda$ is likewise identical.

${ }^{24}$ Series: 'Compensation of employees' and 'Gross operating surplus and gross mixed income' from OECD Annual National Accounts. Source of other data used in this Section: OECD Annual National Accounts and International Financial Statistics.
} 
measure is $i$ 's export price index relative to a weighted average of the export prices of the remaining G7 countries. The resulting terms of trade measures are logged and linearly detrended to construct $\widehat{q} \cdot{ }^{25}$

For each country, we regressed its relative wage income $\widehat{w_{t} l_{t}}$ and dividend $\widehat{d}_{t}$ on $\widehat{q_{t}}$; the correlation between the residuals of those regressions is our estimate of $\operatorname{Corr}_{\widehat{q}}\left(\widehat{w_{t} l_{t}}, \widehat{d}_{t}\right)$, for that country. For all countries, the two (detrended) terms of trade measures are highly positively correlated (average correlation: 0.86), and the implied values of $\operatorname{Corr}_{\widehat{q}}\left(\widehat{w_{t} l_{t}}, \widehat{d}_{t}\right)$ are thus mostly similar across the two terms of trade measures. Panel (b) of Table 1 shows that, when the first terms of trade measure is used, the conditional correlation $\operatorname{Corr}_{\widehat{q}}\left(\widehat{w_{t} l_{t}}, \widehat{d}_{t}\right)$ is negative, for all G7 countries. The second terms of trade measure yields $\operatorname{Corr} \widehat{\widehat{q}}\left(\widehat{w_{t} l_{t}}, \widehat{d}_{t}\right)<0$ for all G7 countries, with the exception of Italy (see Panel (c)).

\section{Implied equity portfolios}

Across G7 countries, the average capital share is $\kappa=0.4$; the average ratio of gross physical investment to GDP is $\Lambda=0.22$. The mean values (1984-2004) of the G7 countries's shares in total G7 GDP are: 0.44 (US), 0.19(Japan), 0.11 (Germany), 0.08(France), 0.06 (UK), 0.06 (Italy) and 0.04 (Canada). Using these values for $\kappa, \Lambda$ and $\mu_{i}$, and estimates of $\operatorname{Cov}_{\widehat{q}}\left(\widehat{w_{t} l_{t}}, \widehat{d}_{t}\right) / \operatorname{Var}_{\widehat{q}}\left(\widehat{d}_{t}\right)$, we compute locally held equity shares $S_{i}^{i}$ predicted by the model (see (38)). The results are likewise shown in Table 1 . The predicted degrees of equity home bias $S_{i}^{i}-\mu_{i}$ are mostly sizable and highly statistically significant. For example, based on the first terms of trade measure, the equity home bias ranges between 14\% (US, Canada) and $84 \%$ (Japan); the implied locally held equity share $S_{i}^{i}$ ranges between $18 \%$ (Canada) and $103 \%$ (Japan).

\subsection{Returns and the equilibrium portfolio}

The preceding discussion shows that the zero-order local equity position $S$ depends on the conditional covariance between relative (Home vs. Foreign) wage incomes and dividend payments. As shown in the Technical Appendix, $S$ can equivalently be expressed as a function of the covariance between components of relative (Home vs. Foreign) human capital returns and equity returns that are orthogonal to the

\footnotetext{
${ }^{25}$ Note that in the model here, the terms of trade and the real exchange rate are perfectly positively correlated. Mendoza (1995) and Obstfeld and Rogoff (2000) report high positive correlations between real exchange rates and the terms of trade, for G7 countries. Below, we use a CPI based real exchange rate as our empirical RER measure. That RER measure is highly positively correlated with our two empirical terms of trade measures (average correlation with first [second] t.o.t. measure: 0.99 [0.85]).
} 
return differential between the Home-good and Foreign-good bonds; equity home bias is optimal when this conditional covariance is negative.

Looking at stock returns and estimated returns on human capital for G7 countries, Coeurdacier and Gourinchas (2009) provide evidence that the conditional covariance between the two is very different from the unconditional one. ${ }^{26}$ The former being negative when significant (for the US and Japan and to a lesser extent UK and Canada) while the latter is unambiguously positive (very much like our estimates based on on income payments). Quantitatively, Coeurdacier and Gourinchas find that for the US and Japan, the conditional covariance between returns on human capital (relative to other G7 countries) and (relative) returns on stocks is negative enough to match the observed equity home bias for these countries. $^{27}$

\section{The dynamics of external financial positions}

This Section describes the dynamics of the external financial positions of G7 countries; we then show that our model captures key aspects of the observed dynamics.

\subsection{External position dynamics: empirical evidence}

Table 2 reports standard deviations and (auto)correlations of annual financial/macroeconomic variables for the G7 countries, during the period 1984-2004. All statistics pertain to series that were detrended using the Hodrick-Prescott filter (smoothing parameter: 400). GDP, physical investment and real exchange rate series (CPI-based) were logged, before applying the filter.

\section{[INSERT TABLE 2 ABOUT HERE]}

The Table reports properties of the first difference (annual change) of countries' Net Foreign Assets (NFA) at market prices; see rows labeled " $\triangle \mathrm{NFA"} \mathrm{(NFA} \mathrm{changes} \mathrm{are} \mathrm{normalized} \mathrm{by} \mathrm{domestic} \mathrm{nominal}$

\footnotetext{
${ }^{26}$ Mixed evidence on the unconditional correlation between returns on human wealth and returns on stocks is provided by Baxter and Jermann (1997), Bottazzi et al. (1996), Palacios-Huerta (2001) and Julliard (2004). Note that, in a setting with trade in domestic and foreign currency bonds (as assumed here), the unconditional correlation between these returns is irrelevant for the equilibrium equity portfolio. Only the conditional correlation matters.

${ }^{27}$ Coeurdacier and Gourinchas (2009) report that the covariance of (relative) stock returns with (relative) returns on human wealth divided by the variance of stock returns (conditional on relative bond returns) is -0.26 (resp. - 0.33 ) for the US (resp. Japan). For the Euro zone countries, results are much less conclusive. For these countries, it is possible that stock returns are not a good proxy for returns on firm value as a smaller share of capital is sold on equity markets.
} 
GDP). ${ }^{28}$ For 6 of the G7 countries, $\triangle$ NFA is more volatile than GDP; the mean standard deviations of $\triangle$ NFA and GDP across the G7 countries are $3.23 \%$ and $2.07 \%$, respectively (see last Column of Table 2). NFA changes are countercyclical and essentially serially uncorrelated (mean correlation with domestic GDP: -0.22; mean autocorrelation: -0.01 )

As our model assumes trade in stocks and in bonds, we decompose the change of each country's NFA into the change of its net foreign equity assets and into the change of its net foreign bond assets, at market prices (normalized by domestic GDP). ${ }^{29}$ Equities and bonds both contribute noticeably to NFA changes: the average standard deviations of (normalized) changes of net foreign equity assets and of net foreign bond assets are $2.97 \%$ and $2.20 \%$, respectively. Changes in net foreign equity assets and net foreign bond assets are negatively correlated (mean correlation: -0.27). Like NFA changes, the changes of net foreign equity and net foreign bond positions have weak serial correlation; the changes of net foreign bond assets are countercyclical, while the changes of net foreign equity assets have no clear cyclical pattern.

The changes in the net foreign equity/bond assets at market prices reflect asset price (and exchange rate) changes, as well as net foreign asset acquisitions. The net foreign asset acquisition by a country, in a given period, is measured by its current account $(\mathrm{CA})$. In contrast to the first difference of NFA (at market prices), the CA does not take into account external capital gains/losses (on assets acquired in the past). Table 2 reports time series properties of the CAs of the G7 countries; we also disaggregate the CAs into 'Net equity purchases' from the rest of the world and 'Net bond purchases'. ${ }^{30}$ (CA and net equity/bond purchases series are normalized by domestic GDP). The CAs are only about a third as volatile as the NFA change (the mean standard deviation of $\mathrm{CA}[\Delta \mathrm{NFA}]$ is $1.11 \%[3.23 \%]$ ). ${ }^{31}$ Thus, NFA changes are largely driven by valuation changes. Net equity purchases (mean standard deviation: $1.38 \%$ ) and net bond purchases (mean standard deviation: 1.71\%) are only sightly more volatile than the CA. Net equity/bond purchases are less volatile than changes in net foreign equity/bond positions

\footnotetext{
${ }^{28}$ The NFA data are from Lane and Milesi-Ferretti (2006). Unless stated otherwise, the other data in this Section are from OECD National Accounts (macroeconomic aggregates, price indices) and International Financial Statistics (exchange rates).

${ }^{29}$ We measure a country's net equity as the sum of its net portfolio equity and net FDI positions; the net bond position is the sum of net debt and net bank loans (data from Lane and Milesi-Ferretti (2006)).

${ }^{30}$ Data source: IMF Balance of Payments Statistics. Our Net equity purchases variable is constructed as outflows minus inflows of 'Portfolio investment equity securities' + 'Direct investment'. Our Net debt purchases series represents outflowsinflows of 'portfolio investment debt securities' inflows + 'Other investment'.

${ }^{31}$ Kollmann (2006b) previously documented that CAs are less volatile than NFA changes, for a sample of.18 OECD countries. Faruquee and Lee (2007) confirm this empirical result for a sample of 100 countries.
} 
at market prices; the difference is especially noticeable for equities-which suggests that, valuation effects are more important for stocks than for bonds. Interestingly, net equity purchases are highly negatively (statistically significantly) correlated with net debt purchases (mean correlation: -0.68).

Finally, we note that net exports (normalized by GDP) are less volatile than GDP, while physical investment and the real exchange rate (CPI-based) are more volatile than GDP (mean standard deviations

of GDP, NX and RER: $2.07 \%, 1.14 \%$ and $8.38 \%$, respectively). Net exports are negatively correlated with domestic GDP (in 6 of the G7 countries), while the real exchange rate has no clear cyclical pattern (mean correlation with GDP: 0.12).

\subsection{External position dynamics: model predictions}

We now study the predictions of the model for the dynamics of foreign asset positions, capital flows and of key macroeconomic variables. We compare these predictions to the stylized facts described in the previous section.

\subsubsection{Model calibration}

We adopt a model calibration that closely follows the International Real Business Cycle literature (e.g. Backus, Kehoe and Kydland (1994), Kollmann (1996, 1998)). Like Backus et al., we set the degrees of consumption and investment home bias at $a=a_{I}=0.85$, which implies that the trade share (imports/GDP ratio) is $15 \%$ in the (deterministic) steady state.

The risk aversion coefficient, the labor supply elasticity, the substitution elasticity between domestic and foreign goods and the labor share (ratio of wage earnings to GDP) are set at $\sigma=2,1 / \omega=2, \phi=$ $\phi_{I}=2$ and $1-\kappa=0.6$, respectively; these parameter values are well in the range of empirical parameter estimates, for G7 countries (see Coeurdacier, Kollmann and Martin (2007) for a detailed justification).

The model is calibrated to annual data. As is standard in annual macro models, we set the subjective discount factor and the depreciation rate of capital at $\beta=0.96$ and $\delta=0.1$, respectively. This implies that, in steady state, the return on equity is about $4.16 \%$ p.a., the capital-output ratio is 2.82 , and $28 \%$ of GDP is used for investment. 
We assume that the exogenous variables follow $\mathrm{AR}(1)$ processes:

$$
\begin{aligned}
& \log \left(\theta_{i, t}\right)=\rho^{\theta} \log \left(\theta_{i, t-1}\right)+\varepsilon_{i, t}^{\theta}, \\
& \log \left(\chi_{i, t}\right)=\rho^{\chi} \log \left(\chi_{i, t-1}\right)+\varepsilon_{i, t}^{\chi} \quad \text { for } i=H, F .
\end{aligned}
$$

We fitted (39) to detrended annual (log) TFP series, for each G7 country (1972-2004). ${ }^{32}$ The estimates of $\rho^{\theta}$ range between 0.64 (US) and 0.80 (Canada); the mean autocorrelation (across G7 countries) is 0.75 . The standard deviation of $\varepsilon_{i, t}^{\theta}$ ranges between $1.01 \%$ (France) and $1.48 \%$ (Japan), with a mean of $1.20 \%$. TFP is positively correlated across countries; for each G7 country, we constructed a measure of 'foreign' TFP, by taking a weighted average (using GDP weights) of (log) TFP in the remaining G7 countries; we then fitted (39) to (linearly detrended) 'foreign' (log) TFP. The correlation of domestic-foreign productivity innovation ranges between 0.29 (UK) and 0.70 (Germany), with an average correlation of 0.45 . We thus set $\rho^{\theta}=0.75, \operatorname{Std}\left(\varepsilon_{H, t}^{\theta}\right)=\operatorname{Std}\left(\varepsilon_{F, t}^{\theta}\right)=1.20 \%, \operatorname{Corr}\left(\varepsilon_{H, t}^{\theta}, \varepsilon_{F, t}^{\theta}\right)=0.45 . \quad 33$

When $a=a_{I}$ holds, one unit of the country $i$ aggregate investment good in efficiency units is worth $1 / \chi_{i, t}$ units of the aggregate consumption good in that country. The literature on investment specific technology shocks has used the ratio of the CPI to the price deflator of investment spending as an estimate of investment specific technology shocks (see Fisher (2006)). We follow that literature. For each G7 country, we computed annual time series of $\chi_{i, t} \equiv \mathrm{CPI} /($ investment deflator), for the period 1972-2004 (data source: OECD National Accounts). ${ }^{34}$ The autocorrelations of (linearly detrended) $\log \left(\chi_{i, t}\right)$ range between 0.54 (Japan) and 0.93 (US); the mean autocorrelation is 0.79 . The standard deviations of $\varepsilon_{i, t}^{\chi}$ ranges between $1.18 \%$ (US) and $2.48 \%$ (UK), with a mean of $1.73 \%$. Innovations to investment efficiency in country $i$ and in a rest-of-G7 aggregate are only weakly correlated (mean correlation: 0.19). Empirically, $\log \left(\chi_{i, t}\right)$ is thus roughly as persistent as $\log \left(\theta_{i, t}\right)$, but more volatile, and less correlated across countries. Based on this evidence, we set $\rho^{\chi}=0.79, \operatorname{Std}\left(\varepsilon_{H, t}^{\chi}\right)=\operatorname{Std}\left(\varepsilon_{F, t}^{\chi}\right)=1.73 \%, \operatorname{Corr}\left(\varepsilon_{H, t}^{\chi}, \varepsilon_{F, t}^{\chi}\right)=0.19$.

\footnotetext{
${ }^{32}$ Our estimate of country i TFP (in $\left.\operatorname{logs}\right)$ is: $\log \left(T F P_{i, t}\right)=\log \left(y_{i, t}\right)-\left(1-\kappa_{i}\right) \log \left(l_{i, t}\right)$, with $1-\kappa_{i}$ : i's mean labor share during the sample period; $L_{i, t}$ : total hours worked (from OECD Productivity Database). No capital stocks were used, due to the absence of consistent capital data in G7 countries, during sample period.

${ }^{33}$ We also estimated VARs in home and foreign TFP: $\left(\log \left(\theta_{H, t}\right), \log \left(\theta_{F, t}\right)\right)=R\left(\log \left(\theta_{H, t-1}\right), \log \left(\theta_{F, t-1}\right)\right)+\epsilon_{t}^{\theta}$ where $R$ is a $2 \times 2$ matrix. We find that the off-diagonal elements of $R$ are generally not statistically significant; the mean value (across G7 countries) of the off-diagonal elements is zero. The simulations thus assume univariate technology processes with innovations that are correlated across countries.

${ }^{34}$ The empirical literature on investment specific technology shocks has focused on the US. It documents a secular fall in the real price of investment goods (relative to the CPI). Our data show that a similar downward trend exists in the remaining G7 countries. In 1972-2004, the average annual rates of decline of the relative price of investment were: $0.99 \%$ (US), $0.84 \%$ (Japan), $0.52 \%$ (Germany) $0.35 \%$ (France), 0.66\% (UK), 0.32\% (Italy), $1.33 \%$ (Canada).
} 
The correlations between TFP and investment efficiency innovations $\left(\varepsilon_{i, t}^{\theta}, \varepsilon_{i, t}^{\chi}\right)$ are close to zero (mean correlation: 0.0003). In the calibration, we thus assume that TFP and investment efficiency shocks are independent.

\subsubsection{Numerical solution method}

We numerically solve for first-order accurate prices, quantities and (time-varying) equilibrium portfolios, building on Devereux and Sutherland (2006b). ${ }^{35}$ The numerical solution expresses portfolios held at the end of period $t$ as a linear function of endogenous predetermined variables set at $t$, and of exogenous

variables realized at $t: S_{j, t+1}^{i}=S_{j}^{i}+\gamma_{j}^{S, i}\left(Z_{t}-Z\right), b_{j, t+1}^{i}=b_{j}^{i}+\gamma_{j}^{b, i}\left(Z_{t}-Z\right)$ for $i, j=H, F$, with $Z_{t} \equiv\left(K_{H, t+1}, K_{F, t+1}, N F A_{H, t+1}, \theta_{H, t}, \theta_{F, t}, \chi_{H, t}, \chi_{F, t}\right)$, where $N F A_{H, t}$ is the Home country net foreign asset position at the end of period $t$ (see below). The coefficients $\gamma_{j}^{S, i}, \gamma_{j}^{b, i}$ of these linear portfolio decision rules can be computed using a third-order accurate approximation of the household Euler equations, and a second-order accurate approximation of the remaining equilibrium conditions. We use the Sims (2000) algorithm for that purpose.

\subsubsection{Numerical results}

Table 3 shows predicted moments of (first-order accurate) Home country variables. Net foreign assets, net foreign equity/bond assets, the current account, net equity/bond purchases and net exports are normalized by Home GDP. Statistics for (real) GDP and physical investment pertain to logged series. All statistics are based on Hodrick-Prescott filtered variables (smoothing parameter: 400). ${ }^{36}$ That normalization/filter parallels the normalization/filter applied to the empirical series in Table 2.

\section{[INSERT TABLE 3 ABOUT HERE]}

The theoretical counterparts to the empirical financial variables considered in Table 2 are defined as follows: The Home country's net foreign equity assets (at market prices) at the end of period t are $p_{F, t}^{S} S_{F, t+1}^{H}-p_{H, t}^{S} S_{H, t+1}^{F}$, while Home net foreign bond assets (at market prices) are: $p_{H, t}^{b} b_{H, t+1}^{H}+p_{F, t}^{b} b_{F, t+1}^{H}$. Net Foreign Assets are the sum of net foreign equity assets and net foreign bond assets. The Home net

\footnotetext{
${ }^{35}$ Devereux and Sutherland (2006b) compute dynamic portfolios in an economy with two assets; we extend their method to the case with more than two assets.

${ }^{36}$ Predicted moments are computed by applying the Hodrick-Prescott filter to the moving average representation of the linearized model solution (using formulae for Hodrick-Prescott filter weights derived by McElroy (2008)).
} 
equity purchase in period t is $p_{F, t}^{S} \Delta S_{F, t+1}^{H}-p_{H, t}^{S} \Delta S_{H, t+1}^{F}$ (with $\left.\Delta x_{t+1} \equiv x_{t+1}-x_{t}\right)$; the Home net bonds purchase is $p_{H, t}^{b} \Delta b_{H, t+1}^{H}+p_{F, t}^{b} \Delta b_{F, t+1}^{H}$. The current account is the sum of net bond and equity purchases. Up to the linear approximation used here, the change in a country's NFA equals the current account plus the change in market value of steady state external stock and bond holdings: $\triangle N F A_{H, t+1}=$ $C A_{H, t}+\left(\Delta p_{F, t}^{S}-\Delta p_{H, t}^{S}\right)(1-S)+\left(\Delta p_{H, t}^{b}-\Delta p_{F, t}^{b}\right) b .{ }^{37}$ Similarly, the change in net foreign equity [bond] assets (at market prices) equals net equity [bond] purchases, plus the change in the market value of the steady state stock [bond] holdings. In Table 3 (as in the model) we define the real exchange rate as the relative price of Home aggregate consumption in terms of Foreign aggregate consumption; see (21) (thus, a fall in $R E R_{t}$ represents a depreciation of the Home real exchange rate).

\section{Zero-order portfolio}

The zero-order equilibrium portfolio is: $S=0.79, \widetilde{b}=0.26$. Thus, $79 \%$ of a country's capital stock is predicted to be held by local investors.

\section{Predicted dynamic properties}

Col. 1 of Table 3 reports predicted statistics for the model, with the two types of shocks. In order to assess the relative importance of each type of shock, we also report predicted statistics for variants with only TFP shocks (Col. 2) and with only investment efficiency shocks (Col. 3). ${ }^{38}$ Col. 4 reports average historical statistics for the G7 countries.

Table 3 shows that the model generates sizable fluctuations in equity and bond holdings: the predicted standard deviations of a country's net bond purchases and of its net equity purchases are both $3.23 \%$ (the mean empirical standard deviations of net bond and net equity purchases are $1.71 \%$ and $1.38 \%$, respectively); the $\theta$ and $\chi$ shocks both account for roughly the same share of the variance of net equity/bond purchases. However, up to a first order approximation, these net asset purchases do not affect the current account: in each period, the value of net equity purchases equals the value of net bond sales (see proof in Technical Appendix). The model thus predicts that net bond purchases are perfectly negatively correlated with net equity purchases. Empirically, net bond purchases and net equity

\footnotetext{
${ }^{37}$ To see this, note that, up to first order, the country $\mathrm{H}$ current account, and the first difference of H's net foreign assets are $C A_{H, t}=p^{S}\left(\Delta S_{F, t+1}^{H}-\Delta S_{H, t+1}^{F}\right)+p^{b}\left(\Delta b_{H, t+1}^{H}+\Delta b_{F, t+1}^{H}\right), \Delta N F A_{H, t+1}=p^{S}\left(\Delta S_{F, t+1}^{H}-\Delta S_{H, t+1}^{F}\right)+p^{b}\left(\Delta b_{F, t+1}^{H}+\right.$ $\left.\Delta b_{H, t+1}^{F}\right)+\left(\Delta p_{F, t}^{S}-\Delta p_{H, t}^{S}\right)(1-S)+\left(\Delta p_{H, t}^{b}-\Delta p_{F, t}^{b}\right) b$.

${ }^{38}$ Cols. 2 and 3 assume the equilibrium decision rules and price functions of the model with both types of shocks - we merely feed just one type of disturbances into the model.
} 
purchases are strongly negatively correlated (mean correlation: -0.68).

The model captures the fact that the persistence of net equity/bond purchases is much lower than the persistence of GDP: the predicted autocorrelations of net equity and net bond purchases are close to zero (0.07). This is due to the fact that equity and bond holdings at the end of period $t\left(S_{i, t+1}^{j}, b_{i, t+1}^{j}\right)$ are functions of state variables (capital stocks, Net Foreign Assets and exogenous variables) that are highly persistent; thus, the first difference of net equity/bond holdings (i.e. net equity/bond purchases) has little serial correlation.

The predicted standard deviation, correlation with GDP and autocorrelation of the first difference of Net Foreign Assets (with simultaneous two types of shocks) are 2.21\%, -0.26 and 0.12 , respectively (corresponding average empirical statistics: $3.23 \%,-0.22,-0.01$ ). Consistent with the data, the model predicts thus that the change of NFA is more volatile than GDP, countercyclical and basically serially uncorrelated. As the current account is predicted to be zero (up to first order), NFA changes are solely driven by movements in asset prices. NFA is thus predicted to have the time series properties of asset prices. When there is a positive TFP or investment efficiency shock, net imports are predicted to rise on impact (due to a strong short run rise in investment), and to fall thereafter; the present value of future net imports drops, on impact. As the country's NFA equals the present value of its current and future net imports, the NFA drops too on impact. This explains why the change in NFA is predicted to be countercyclical.

With just TFP shocks [just investment efficiency shocks] the predicted standard deviation of the change in NFA is $1.72 \%$ [1.39\%] (see Cols., 2 and 3, Table 3). Thus, investment efficiency shocks contribute noticeably to the model's ability to generate volatile NFA changes.

The changes of net foreign equity assets and of net foreign bond assets too are predicted to exhibit sizable fluctuation (predicted standard deviations with the two simultaneous types of shocks: $5.32 \%$ and $3.13 \%$, respectively). As in the data, the changes of net equity assets and of net bond assets are negatively correlated.

The model (with simultaneous $\theta$ and $\chi$ shocks) matches closely the observed volatility of GDP, and it captures the fact that investment spending is markedly more volatile than GDP (predicted standard deviations of GDP and investment: $1.87 \%, 8.26 \%$ ). The predicted standard deviation of net exports 
$(1.07 \%)$ is close to the empirical standard deviation (1.14\%). The model predicts that net exports are weakly countercyclical. Cols. 2 and 3 show that TFP shocks are the main source of output fluctuations, but that investment and net exports are mainly driven by investment efficiency shocks $(\chi) . \quad \chi$ also generates countercyclical fluctuations of net exports. The model captures the fact that the fluctuations of GDP, investment and net exports are persistent.

The high volatility of the real exchange rate is one of the key puzzles of international macroeconomics. Standard RBC models (driven just by TFP shocks) underpredict sharply the observed volatility of real exchange rates; those models also predicts that the real external value of a currency (and the terms of trade) is highly countercyclical (see, e.g., Backus et al. (1994)). The model here, with the two types of shocks, performs somewhat better. With just TFP shocks, the predicted standard deviation of the real exchange rate and its correlation with domestic GDP are $0.60 \%$ and -0.52 , respectively. Adding the investment efficiency shock more than doubles the predicted standard deviation of the real exchange rate (to $1.38 \%$ ), and raises the predicted correlation with GDP to -0.22 (the empirical correlation is 0.08). However, quantitatively the model is still far from accounting for observed real exchange rate volatility.

When there are just $\chi$ shocks, the real exchange rate is essentially acyclical. On impact, a positive Home investment efficiency shock appreciates the Home country's terms of trade and its real exchange rate (the increase in Home investment triggered by the shock raises relative demand for the $\mathrm{H}$ good, as there is local bias in investment spending); however, in subsequent periods, the real exchange rate depreciates (once Home has increased its capital stock, the supply of the $\mathrm{H}$ good is above its pre-shock level, and thus its relative prices is lower). This explains why, with the simultaneous two types of shock, the real exchange rate is much less cyclical than with just TFP shocks.

The presence of investment efficiency shocks lowers the predicted cross-country correlations of output, consumption and investment. This brings the predicted cross-country consumption correlation (0.58) closer to the empirical correlation (0.44); however, the predicted cross-country output correlation and (especially) the cross-country investment correlation are too low when there are investment efficiency shocks. Also, investment efficiency shocks generate a predicted within-country correlation between consumption and GDP (0.38) that is lower than the empirical correlation (0.78). Raffo (2008), following Jaimovich and Rebelo (2009), addresses these issues by introducing variable capital utilization and Greenwood, Her- 
cowitz, Huffman (1988) preferences into an international business cycle model with investment-specific technology shocks. Variable capital utilization would leave the equilibrium portfolio unchanged. The GHH preferences are non-separable in consumption and leisure; these preferences imply zero wealth effect of shocks on hours worked, while making consumption more responsive to wealth changes; this allows to generate a consumption-investment correlation that is larger, and thus closer to the data. However, due to the assumed non-separability between consumption and leisure, a new hedging motive in portfolio choice appears, namely the hedging of the relative price of leisure. We leave for future research the study of the impact of these non-separable preferences between leisure and consumption on international portfolios holdings.

\section{Conclusion}

This paper departs from the two familiar explanations of equity home bias: transaction costs that impede international diversification, and the possibility that terms of trade responses to supply shocks provide international risk sharing, so that households have little incentive to hold diversified portfolios (Cole and Obstfeld (1991), Helpman and Razin (1978)). We study a two-country/two-good RBC model with frictionless international trade in stocks and in bonds; there are shocks to total factor productivity and to the efficiency of physical investment. In the setting here, domestic stocks are used to hedge fluctuations in local wage income triggered by shocks to investment spending. Terms of trade risk is hedged using bonds denominated in local goods and in foreign goods. In contrast to related models, the low level of international diversification does not depend on strongly countercyclical terms of trade. 


\section{- References}

[1] Acemoglu D. and J. Ventura, 2002. The World Income Distribution. Quarterly Journal of Economics $117,659-94$.

[2] Adler, M. and B. Dumas, 1983. International Portfolio Choice and Corporation Finance: a Synthesis. Journal of Finance 38, 925-984.

[3] Backus, D., and G.W, Smith, 1993. Consumption and Real Exchange Rates in Dynamic Economies with Non-traded Goods. Journal of International Economics 35, 297-316.

[4] Backus, D., P. Kehoe and F. Kydland, 1994. Dynamics of the Trade Balance and the Terms of Trade: The J-Curve? American Economic Review 84, 84-103.

[5] Baxter, M. and U. Jermann, 1997. The International Portfolio Diversification is Worse Than You Think. American Economic Review 87, 170-80.

[6] Bottazzi, L., P. Pesenti and E. van Wincoop, 1996. Wages, Profits and the International Portfolio Puzzle. European Economic Review 40, 219-254.

[7] Cantor R. and N. Mark, 1988. The International Transmission of Real Business Cycles. International Economic Review 29, 493-507.

[8] Castello M., 2007. A New Open Economy Macroeconomic Model with Endogenous Portfolio Diversification and Firm Entry. Working Paper, European University Institute.

[9] Coeurdacier, N., 2009. Do Trade Costs in Goods Markets Lead to Home Bias in Equities? Journal of International Economics 77, 86-100.

[10] Coeurdacier, N. and S. Guibaud, 2008. A Dynamic Equilibrium Model of Imperfectly Integrated Financial Markets. Working Paper, London Business School.

[11] Coeurdacier, N., R. Kollmann and P. Martin, 2007. International Portfolios with Supply, Demand and Redistributive Shocks. NBER International Seminar on Macroeconomics 2007, 231263.

[12] Coeurdacier, N. and Gourinchas P-O, 2009. Home Bias in Goods and Assets: the Role of Bond Trading. Working Paper, University of California, Berkeley. 
[13] Cole, H., M. Obstfeld, 1991. Commodity Trade and International Risk Sharing: How Much do Financial Markets Matter? Journal of Monetary Economics 28, 3-24.

[14] Collard, F., H. Dellas, B. Diba and A. Stockman, 2007. Home Bias in Goods and Assets. Mimeo, Working Paper, IDEI-University of Toulouse.

[15] Corsetti, G., L. Dedola and S. Leduc, 2007. International Risk-Sharing and the Transmission of Productivity Shocks. Review of Economic Studies 75, 443-473.

[16] Devereux, M. and M. Saito, 2005. A Portfolio Theory of International Capital Flows. Working Paper, University of British Columbia.

[17] Devereux, M. and A. Sutherland, 2006a. Solving for Country Portfolios in Open Economy Macro Models. Working Paper, University of British Columbia and St. Andrews University.

[18] Devereux, M. and A. Sutherland, 2006b. Country Portfolio Dynamics. Working Paper, University of British Columbia and St. Andrews University.

[19] Engel, C. and A. Matsumoto, 2006. Portfolio Choice in a Monetary Open-Economy DSGE Model. Working Paper 12214, National Bureau of Economic Research.

[20] Evans, M. and V. Hnatkovska, 2005. International Capital Flows Returns and World Financial Integration. Working Paper 11701, National Bureau of Economic Research.

[21] Evans, M. and V. Hnatkovska, 2007. Solving General Equilibrium Models with Incomplete Markets and Many Financial Assets. Working Paper, Georgetown University.

[22] Faruqee, H. and J. Lee, 2007. Global Dispersion of Current Accounts: Is the Universe Expanding? Working Paper, IMF.

[23] Fisher, J., 2002. Technology Shocks Matter. Working Paper, Federal Reserve Bank of Chicago.

[24] Fisher, J., 2006. The Dynamic Effects of Neutral and Investment-Specific Technology Shocks. Journal of Political Economy 114, 413-52.

[25] French, K. and J. Poterba, 1991. Investor Diversification and International Equity Markets. American Economic Review 81, 222-26.

[26] Ghironi, F., J. Lee and A. Rebucci, 2006. The Valuation Channel of External Adjustment. Working Paper, Boston College. 
[27] Gourinchas, P-O and H. Rey, 2007. International Financial Adjustment. Journal of Political Economy 115, 665-703.

[28] Greenwood, J., Z. Hercowitz and P. Krusell, 1997. Long-Run Implications of InvestmentSpecific Technological Change. American Economic Review, American Economic Association $87,342-62$.

[29] Greenwood, J., Z. Hercowitz and P. Krusell, 2000. The Role of Investment-Specific Technological Change in the Business Cycle. European Economic Review 44, 91-115.

[30] Greenwood, J., Z. Hercowitz and G. Huffman, 1988. Investment, Capacity Utilization and the Real Business Cycle. American Economic Review 78, 402-17.

[31] Hau, H. and H. Rey, 2004. Can Portfolio Rebalancing Explain the Dynamics of Equity Returns, Equity Flows and Exchange Rates? American Economic Review P\&P 94, 126-133.

[32] Heathcote, J. and F. Perri, 2002. Financial Autarky and International Business Cycles. Journal of Monetary Economics 49, 601-627.

[33] Heathcote, J. and F. Perri, 2004. Financial Globalization and Real Regionalization. Journal of Economic Theory 119, 207-243.

[34] Heathcote, J. and F. Perri, 2007. The International Diversification is Not as Bad as You Think. Working Paper 13483, National Bureau of Economic Research.

[35] Helpman, E. and A. Razin, 1978. A Theory of International Trade Under Uncertainty. Academic Press, New York.

[36] Hnatkovska, V., 2005. Home Bias and High Turnover: Dynamic Portfolio Choice with Incomplete Markets. Working Paper, Georgetown University.

[37] Imbs, J. and I. Méjean, 2008. Elasticity Optimism. Working Paper, University of Lausanne.

[38] Julliard, C., 2004. Human Capital and International Portfolio Choice. Working Paper, Princeton University.

[39] Jaimovich, Nir and Sergio Rebelo, 2009. Can News About the Future Drive the Business Cycle?, forthcoming, American Economic Review. 
[40] Julliard, C., 2002. International Portfolio Diversification Is Not Worse Than You Think. Working Paper, Princeton University.

[41] Justiniano, A. and G. Primiceri, 2006. The Time Varying Volatility of Macroeconomic Fluctuations. Working Paper 12022, National Bureau of Economic Research.

[42] Justiniano, A., G. Primiceri and A. Tambalotti, 2007. Investment Shocks and Business Cycles. Working Paper, Northwestern University.

[43] Kollmann, R., 1991. Essays on International Business Cycles, PhD Dissertation, Economics Department, University of Chicago.

[44] Kollmann, R., 1995. Consumption, Real Exchange Rates and the Structure of International Asset Markets. Journal of International Money and Finance 14, 191-211.

[45] Kollmann, R., 1996. Incomplete Asset Markets and the Cross-Country Consumption Correlation Puzzle. Journal of Economic Dynamics and Control 20, 945-962.

[46] Kollmann, R., 1998. US Trade Balance Dynamics: The Role of Fiscal Policy and Productivity Shocks and of Financial Market Linkages. Journal of International Money and Finance 17, 637-69.

[47] Kollmann, R., 2006a. A Dynamic General Equilibrium Model of International Portfolio Holdings: Comment. Econometrica 74, 269-273.

[48] Kollmann, R., 2006b. International Portfolio Equilibrium and the Current Account. Working Paper 5512, Centre for Economic Policy Research.

[49] Kollmann, R., 2006c. Comment on 'International Prices and Productivity: an Empirical Analysis of the Transmission among OECD Countries'. NBER International Seminar on Macroeconomics 2006, 186-194.

[50] Kraay, A., N. Loayza, L. Serven and J. Ventura, 2005. Country Portfolios. Journal of the European Economic Association 3, 914-945.

[51] Lane, P. and G.M. Milesi-Feretti, 2003. International Financial Integration. IMF Staff Papers $50,82-113$.

[52] Lane, P. and G.M. Milesi-Ferretti, 2005. A Global Perspective on External Positions. IIIS Discussion Paper 79, Trinity College Dublin. 
[53] Lane, P. and G.M. Milesi-Ferretti, 2006, The External Wealth of Nations Mark II. IMF Working Paper 06-69.

[54] Lane, P. and J. C. Shambaugh, 2007. Financial Exchange Rates and International Currency Exposures. NBER Working Papers 13433, National Bureau of Economic Research.

[55] Lane, P. and J. C. Shambaugh, 2008. The Long and Short of It: Determinants of Foreign Currency Exposure in External Balance Sheets. Working Paper, Dartmouth College.

[56] Lewis, K., 1999. Explaining Home Bias in Equities and Consumption. Journal of Economic Literature 37, 571-608.

[57] Martin, P. and H. Rey, 2004. Financial Super-Markets: Size Matters for Asset Trade. Journal of International Economics 64, 335-361.

[58] Matsumoto, A., 2007. The Role of Nonseparable Utility and Nontradeables in International Business Cycle and Portfolio Choice. Working Paper 7163, IMF.

[59] McElroy, T., 2008. Exact Formulas for the Hodrick-Prescott Filter. Econometrics Journal 11, 209-217.

[60] Mendoza, E., 1995. The Terms of Trade, The Real Exchange Rate and Economic Fluctuations. International Economic Review 36, 101-137.

[61] Obstfeld, M. and K. Rogoff, 1996. Foundations of International Macroeconomics. MIT Press, Cambridge, MA.

[62] Obstfeld, M. and K. Rogoff, 2000. New Directions for Stochastic Open Economy Models. Journal of International Economics 50, 117-153

[63] Obstfeld, M., 2006. International Risk Sharing and the Costs of Trade. Ohlin Lecture, Stockholm School of Economics.

[64] Palacios-Huerta I., 2001. The Human Capital of Stockholders and the International Diversification Puzzle. Journal of International Economics 54, August, 309-331.

[65] Pavlova, A. and R. Rigobon, 2007a. Asset Prices and Exchange Rates. Review of Financial Studies 20, 1139-1181. 
[66] Pavlova, A. and R. Rigobon, 2007b. An Asset-Pricing View of External Adjustment. Working Paper, London Business School.

[67] Raffo, A., 2008. Technology Shocks: Novel Implications for International Business Cycles. Working Paper, Federal Reserve Board.

[68] Sachs, J., 1981. The Current Account and Macroeconomic Adjustment in the 1970s. Brookings Papers on Economic Activity 1981, 201-268.

[69] Sercu, P. and R. Vanpée, 2007. Home Bias in International Equity Portfolios: A Review. Working Paper, Leuven School of Business and Economics.

[70] Sims, C., 2000. Second Order Accurate Solution of Discrete Time Dynamic Equilibrium Models. Working Paper, Princeton University.

[71] Siourounis, G., 2004. Capital Flows and Exchange Rates: an Empirical Analysis. Working Paper, London Business School.

[72] Tesar, L. and I. Werner, 1995. Home Bias and High Turnover. Journal of International Money and Finance 14, 467-92.

[73] Tille, C., 2005. Financial Integration and the Wealth Effect of Exchange Rate Fluctuations. Staff Report 226, Federal Reserve Bank of New York.

[74] Tille, C. and E. van Wincoop, 2007. International Capital Flows. Working Paper 12856, National Bureau of Economic Research.

[75] Uppal, R., 1993. A General Equilibrium Model of International Portfolio Choice. Journal of Finance 48, 529-553.

[76] Warnock, F., 2002. Home Bias and High Turnover Reconsidered. Journal of International Money and Finance 21, 795-805.

[77] Van Nieuwerburgh, S. and L. Veldkamp, 2007. Information Immobility and the Home Bias Puzzle. Working Paper, New York University.

[78] van Wincoop, E. and F. Warnock, 2006. Is Home Bias in Assets Related to Home Bias in Goods? Working Paper 12728, National Bureau of Economic Research. 
Table 1. Correlations between relative labor incomes and dividends, and implied locally held equity shares

US Japan Germany France UK Italy Canada

(a) Unconditional correlations

$\begin{array}{llllllll}\operatorname{Corr}\left(\widehat{\boldsymbol{w}_{\boldsymbol{t}} \boldsymbol{l}}, \widehat{\boldsymbol{d}_{\boldsymbol{t}}}\right) & 0.73 & 0.59 & 0.70 & 0.77 & -0.24 & 0.89 & 0.28 \\ & (.12) & (.08) & (.14) & (.12) & (.12) & (.02) & (.11)\end{array}$

(b) Conditional correlations based on terms of trade measure given by relative GDP deflators

$$
\begin{array}{rrrrrrrr}
\operatorname{Corr}_{\widehat{\boldsymbol{q}}_{\boldsymbol{t}}}\left(\widehat{\boldsymbol{w}_{\boldsymbol{t}} \boldsymbol{I}_{t}}, \widehat{\boldsymbol{d}_{\boldsymbol{t}}}\right) & -0.17 & -0.75 & -0.69 & -0.39 & -0.71 & -0.26 & -0.22 \\
& (.15) & (.05) & (.10) & (.07) & (.11) & (.19) & (.16)
\end{array}
$$

Implied locally held

$\begin{array}{llllllll}\text { equity share } \boldsymbol{S}_{\boldsymbol{i}}^{\boldsymbol{i}} & 0.58 & 1.03 & 0.50 & 0.51 & 0.68 & 0.34 & 0.18 \\ & (.17) & (.16) & (.09) & (.23) & (.13) & (.24) & (.14)\end{array}$

\begin{tabular}{|c|c|c|c|c|c|c|c|}
\hline \multirow{2}{*}{$\operatorname{Corr}_{\widehat{q}_{t}}\left(\widehat{w_{t} I_{t}}, \widehat{d_{t}}\right)$} & -0.27 & -0.61 & -0.22 & -0.25 & -0.74 & 0.87 & -0.50 \\
\hline & (.18) & $(.09)$ & $(.22)$ & (.15) & $(.08)$ & $(.03)$ & (.13) \\
\hline \multicolumn{8}{|c|}{ Implied locally held } \\
\hline equity share $S_{i}^{i}$ & $\begin{array}{l}0.84 \\
(.31)\end{array}$ & $\begin{array}{l}1.22 \\
(.29)\end{array}$ & $\begin{array}{l}0.41 \\
(.30)\end{array}$ & $\begin{array}{l}0.50 \\
(.35)\end{array}$ & $\begin{array}{l}2.58 \\
(.51)\end{array}$ & $\begin{array}{r}-1.73 \\
(.21)\end{array}$ & $\begin{array}{l}1.61 \\
(.59)\end{array}$ \\
\hline
\end{tabular}

(c) Conditional correlations based on terms of trade measure given by relative export prices

Notes

$\operatorname{Corr}\left(\widehat{w_{t} l_{t}}, \widehat{d}_{t}\right)$ : correlation between relative labor income and the relative dividend income in a given country (compared to total labor income and total dividend in remaining G7 countries).

$\operatorname{Corr}_{\widehat{T}_{t}}\left(\widehat{w_{t} \boldsymbol{l}_{t}}, \widehat{d_{t}}\right)$ : correlation between components of relative labor income and the relative dividend income that are orthogonal to terms of trade.

The data are annual, 1984-2004. Figures in parentheses are standard errors (based on GMM). See text for further explanations. 


\begin{tabular}{lrrrrrrrr}
\hline \hline Standard deviations (\%) & US & JA & GE & FR & UK & IT & CA & Mean \\
GDP & 1.58 & 2.94 & 1.67 & 1.61 & 2.12 & 1.76 & 2.80 & 2.07 \\
Investment & 7.17 & 7.66 & 6.08 & 7.40 & 7.20 & 5.07 & 7.65 & 6.89 \\
Net exports & 0.72 & 0.63 & 0.85 & 0.87 & 1.81 & 1.61 & 1.50 & 1.14 \\
(Net foreign assets) & 2.36 & 2.60 & 2.63 & 4.33 & 5.02 & 2.67 & 3.03 & 3.23 \\
(Net foreign bond assets) & 0.85 & 1.60 & 2.88 & 2.37 & 3.18 & 2.59 & 1.91 & 2.20 \\
(N (Net foreign equity assets) & 2.27 & 3.20 & 1.37 & 4.69 & 4.20 & 2.35 & 2.74 & 2.97 \\
Current account & 0.77 & 0.62 & 1.73 & 0.75 & 1.35 & 1.34 & 1.17 & 1.11 \\
Net bond purchases & 0.88 & 1.25 & 2.49 & 1.76 & 2.24 & 1.92 & 1.45 & 1.71 \\
Net equity purchases & 0.90 & 1.02 & 1.59 & 1.67 & 1.75 & 1.70 & 1.06 & 1.38 \\
Real exchange rate & 10.03 & 10.51 & 8.05 & 7.45 & 6.47 & 9.65 & 6.49 & 8.38
\end{tabular}

Correlations with domestic GDP

Net exports $\quad-\mathbf{- 0 . 3 8}$

$\Delta$ (Net foreign assets)

$\underline{-0.27}$

$\Delta$ (Net foreign bond assets) $\quad \underline{\underline{0.37}}$

$\Delta$ (Net foreign equity assets)

Current account

Net bond purchases

Net equity purchases

$\underline{-0.43}$

$\underline{-0.56}$

$\underline{-0.29} \quad \underline{-0.52} \quad-0.5$

$-0.56$

$-0.48$

$\begin{array}{ll}0.01 & -0.39\end{array}$

$\begin{array}{lll}-0.00 & \mathbf{- 0 . 2 4} & -0.18\end{array}$

$-0.23$

$-0.38$

$\mathbf{- 0 . 5 0}$

$\begin{array}{ll}-0.28 & -0.10\end{array}$

$-0.46$

$-0.22$

$\frac{-0.28}{-0.38}$

$-0.10$

$\frac{-0.46}{-0.22}$

$-0.24$

$\begin{array}{lll}\mathbf{0 . 2 0} & \underline{0.31} & 0.11\end{array}$

$\begin{array}{ll}-0.07 & \frac{0.32}{0.17}\end{array}$

$\underline{-0.45} \quad-0.02$

\begin{tabular}{ll}
$\mathbf{0 . 5 2}$ & -0.06 \\
\hline & -0.06
\end{tabular}

$\begin{array}{ll}\mathbf{- 0 . 5 4} & -0.32\end{array}$

$\mathbf{- 0 . 7 4}$

$-0.44$

$\begin{array}{ll}0.18 & -0.40\end{array}$

$\underline{-\mathbf{0 . 7 7}}$

$-0.08$

$\frac{\mathbf{- 0 . 3 5}}{0.07}$

$\underline{-0.59}$

$\frac{-0.54}{0.04}$

$\frac{\mathbf{- 0 . 5 5}}{0.20}$

$\begin{array}{ll}0.00 & -0.22\end{array}$

0.07

$\begin{array}{lll}0.17 & -0.04 & -0.18\end{array}$

$\underline{0.37}$

0.43

$\underline{-0.22}$

$-0.03$

0.12

Autocorrelations

GDP

$\Delta$ (Net foreign assets)

$\begin{array}{lrlrrrrr}\underline{\mathbf{0 . 6 8}} & \underline{\mathbf{0 . 8 4}} & \underline{\mathbf{0 . 6 8}} & \underline{\mathbf{0 . 7 2}} & \underline{\mathbf{0 . 7 6}} & \underline{\mathbf{0 . 7 1}} & \underline{\mathbf{0 . 7 8}} & 0.74 \\ 0.03 & \underline{\mathbf{- 0 . 4 2}} & 0.00 & -0.13 & -0.14 & -0.01 & \underline{\mathbf{0 . 5 8}} & -0.01 \\ \underline{\mathbf{0 . 2 7}} & 0.13 & 0.12 & 0.09 & \underline{\mathbf{0 . 1 4}} & 0.10 & 0.12 & 0.14 \\ \underline{\mathbf{0 . 2 6}} & \underline{\mathbf{- 0 . 2 3}} & 0.12 & -0.17 & -0.16 & 0.17 & 0.16 & 0.02 \\ \underline{\mathbf{0 . 7 1}} & \underline{\mathbf{0 . 4 6}} & \underline{\mathbf{0 . 6 6}} & \underline{\mathbf{0 . 6 7}} & \underline{\mathbf{0 . 7 0}} & \underline{\mathbf{0 . 7 3}} & \underline{\mathbf{0 . 5 5}} & 0.64 \\ \underline{\mathbf{0 . 6 5}} & \underline{\mathbf{0 . 2 6}} & \underline{\mathbf{0 . 6 6}} & 0.11 & 0.17 & \underline{\mathbf{0 . 3 9}} & -0.01 & 0.32 \\ \underline{\mathbf{0 . 5 8}} & -0.00 & \underline{\mathbf{0 . 4 1}} & \underline{\mathbf{0 . 3 5}} & -0.17 & \underline{\mathbf{0 . 5 0}} & -0.08 & 0.23\end{array}$

$\Delta$ (Net foreign bond assets)

$\Delta$ (Net foreign equity assets)

Current account

Net bond purchases

Net equity purchases

$\underline{\mathbf{0 . 5 8}}-0.00$

\section{Other correlations}

$\Delta$ (Net foreign equity assets) \&

$\begin{array}{llllllllll}\Delta \text { (Net foreign bond assets) } & -0.09 & \underline{\mathbf{- 0 . 4 8}} & \underline{\mathbf{- 0 . 3 9}} & \underline{\mathbf{- 0 . 3 9}} & -0.01 & \underline{\mathbf{- 0 . 3 6}} & -0.15 & -0.27\end{array}$

Net equity purchases \&

Net bond purchases

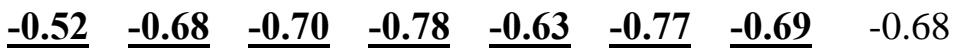

Notes--Data are annual, 1984-2004, and were Hodrick-Prescott filtered. GDP, investment and real exchange rate series were logged. Real exchange rates are CPI-based. Underlined correlations are statistically significant at a $10 \%$ level (two-sided test, GMM based, assuming 4-th order serial correlation in residuals). JA: Japan, GE: Germany, FR: France, IT: Italy, CA: Canada. 
Table 3. Model predictions: dynamic properties

\begin{tabular}{|c|c|c|c|c|}
\hline & $S$ & hocks tc & & \\
\hline & $\begin{array}{l}\theta_{H}, \theta_{F} \\
\chi_{H}, \chi_{F}\end{array}$ & $\theta_{H}, \theta_{F}$ & $\chi_{H}, \chi_{F}$ & Data (G7) \\
\hline Standard deviations (\%) & (1) & (2) & (3) & (4) \\
\hline$G D P$ & 1.87 & 1.65 & 0.88 & 2.07 \\
\hline Consumption & 0.76 & 0.49 & 0.57 & 1.54 \\
\hline Investment & 8.26 & 4.73 & 6.77 & 6.89 \\
\hline Hours worked & 1.31 & 0.63 & 1.14 & 1.89 \\
\hline Net exports & 1.07 & 0.24 & 1.05 & 1.14 \\
\hline$\Delta($ Net foreign assets) & 2.21 & 1.39 & 1.72 & 3.23 \\
\hline $\boldsymbol{\Delta}($ Net foreign bond assets) & 5.32 & 3.69 & 3.82 & 2.20 \\
\hline$\Delta$ (Net foreign equity assets) & 3.13 & 2.31 & 2.11 & 2.97 \\
\hline Net bond purchases & 3.23 & 2.39 & 2.18 & 1.71 \\
\hline Net equity purchases & 3.23 & 2.39 & 2.18 & 1.38 \\
\hline Real exchange rate & 1.38 & 0.60 & 1.24 & 8.38 \\
\hline Correlations with domestic $G$ & & & & \\
\hline Consumption & 0.38 & 0.81 & -0.22 & 0.78 \\
\hline Investment & 0.71 & 0.95 & 0.59 & 0.85 \\
\hline Hours worked & 0.61 & 0.81 & 0.65 & 0.83 \\
\hline Net exports & -0.07 & 0.06 & -0.17 & -0.39 \\
\hline$\Delta($ Net foreign assets) & -0.26 & -0.32 & -0.20 & -0.22 \\
\hline$\Delta$ (Net foreign bond assets) & -0.24 & -0.30 & -0.17 & -0.24 \\
\hline$\Delta$ (Net foreign equity assets) & 0.23 & 0.28 & 0.15 & -0.02 \\
\hline Net bond purchases & -0.27 & -0.30 & -0.22 & -0.22 \\
\hline Net equity purchases & 0.27 & 0.30 & 0.22 & -0.03 \\
\hline Real exchange rate & -0.22 & -0.52 & -0.07 & 0.12 \\
\hline Cross-country correlations & & & & \\
\hline Output & 0.17 & 0.30 & -0.28 & 0.49 \\
\hline Consumption & 0.58 & 0.81 & 0.42 & 0.46 \\
\hline Investment & -0.37 & 0.25 & -0.67 & 0.27 \\
\hline Hours worked & 0.18 & 0.15 & 0.19 & 0.43 \\
\hline Autocorrelations & & & & \\
\hline$G D P$ & 0.59 & 0.55 & 0.76 & 0.74 \\
\hline$\Delta$ (Net foreign assets) & 0.12 & -0.03 & 0.21 & -0.01 \\
\hline$\Delta$ (Net foreign bond assets) & 0.04 & -0.07 & 0.15 & 0.14 \\
\hline$\Delta$ (Net foreign equity assets) & -0.00 & -0.10 & 0.10 & 0.02 \\
\hline Net bond purchases & 0.07 & -0.06 & 0.23 & 0.32 \\
\hline Net equity purchases & 0.07 & -0.06 & 0.23 & 0.23 \\
\hline Other correlations & & & & \\
\hline$\Delta$ (Net foreign equity assets) & & & & \\
\hline$\Delta$ (Net foreign bond assets) & -0.99 & -0.99 & -0.99 & -0.27 \\
\hline Net bond purchases \& & & & & \\
\hline Net equity purchases & -1.00 & -1.00 & -1.00 & -0.68 \\
\hline
\end{tabular}

Notes--The following variables are normalized by domestic GDP: Net exports, $\boldsymbol{\Delta}$ (Net foreign assets), $\Delta$ (Net foreign bond assets), $\Delta$ (Net foreign equity assets), Current account, Net bond purchases, Net equity purchases. GDP, Investment and the Real exchange rate (CPI-based) are logged. All variables are Hodrick-Prescott filtered. The empirical measure of consumption is non-durables plus services expenditures (from OECD National Accounts). The Real exchange rate measure is based on relative prices indices of non-durables and services consumption. 